\title{
Strengthening of Indonesian Borderland at South China Sea Water Area (Strategic Study on Development of Natuna Regency into Province by Formation Natuna Regency)
}

\author{
Fernandes Simangunsong, Imelda Hutasoit \\ Institut Pemerintahan Dalam Negeri (Governmental Institute of Home Affairs), Sumedang, Indonesia \\ Email: kisankiel@yahoo.co.id, fernandes_simangunsong@ipdn.ac.id, www.fernandessimangunsong.com, \\ imelda77_soit@yahoo.com
}

How to cite this paper: Simangunsong, F. and Hutasoit, I. (2018) Strengthening of Indonesian Borderland at South China Sea Water Area (Strategic Study on Development of Natuna Regency into Province by Formation Natuna Regency). Open Journal of Social Sciences, 6, 294-336.

https://doi.org/10.4236/jss.2018.64025

Received: March 28, 2018

Accepted: April 27, 2018

Published: April 30, 2018

Copyright $\odot 2018$ by authors and Scientific Research Publishing Inc. This work is licensed under the Creative Commons Attribution International License (CC BY 4.0).

http://creativecommons.org/licenses/by/4.0/

\begin{abstract}
This study provides an overview of the level of ability of autonomous regions of Natuna Regency-Riau Islands Province on the border of Indonesia, to design the formation of new autonomous regions based on the criteria of regional formation referring to GR. 129 of 2000/No. 78 of 2007, and the Draft Government Regulation on Area Arrangement. This study uses the application of measurement model and evaluation of the ability of a region in the implementation of regional autonomy, so the sample is a saturated sample, where the population consists of 15 districts, 70 villages and 6 sub-urban. This research concludes that the division in Natuna can be designed in 4 alternatives that can become its own province, if the Anambas Islands Regency, which is the division of Natuna Regency also plan the establishment of 1 new autonomous region (NAR), so the requirement for the manufacture of special province, South China Sea waters can be achieved because Natuna will be divided into 3 (three) autonomous regions while the Anambas Islands District will be divided into 2 (two) autonomous regions. 5 (five) autonomous regions shall be the basic requirement for the establishment of 1 (one) autonomous region at the provincial level.
\end{abstract}

\section{Keywords}

Development of Region, Local Government, Province and Regency, Borders of South China Sea, Public Policy

\section{Introduction}

Regional reorganization is activities in stewardship, creation, and elimination of 
region as an integral part of decentralization policy [1]. Scope of regional reorganization, thereby, includes formation or creation of region, elimination and merging region(s), adjustment of borders, changing of regional status both administratively or politically, and relocation of capital city. Indonesia has had policy on regional reorganization. But there are a number of weaknesses as follows:

1) Epistemologically, design of policy is heavily related with inward-looking mindset, thus concept of regional reorganization is merely emphasized on formation of region or creation of New Autonomous Region (NAR). And so is the parameter set as requirement for creation of region, either administrative, technical or territorial requirements;

2) It is still partial, in terms of interests per region are still the main focus. This is seen from the implementation of bottom-up planning approach in the procedure for creation of region [2];

3) Implementation of the design is still fragmented by sector, thus regional reorganization is not optimal while government's burden is increasing [3];

4) To counter these weaknesses, it is required to have more comprehensive, integrative, and global design of reorganization, thereby central government revise Law No. 32 of 2004 by Law No. 23 of 2014 on Local Government. With central government revising GR No. 78 of 2007 in form of Draft Regional Regulation (DRR) in lieu of GR No. 78 of 2007 on Regional Reorganization, there will be a design of regional reorganization that consider all sectors in development, national interests, and opportunities and challenges in globalization era. Thus, regions don't only attempt to improve their social welfare, but also increase national honor and dignity and become international oriented [4].

Phenomena of formation of region that widely occurs in whole Indonesia, are also being talked about in the community of Natuna Regency who think that there is partiality in the development due to great extent of area so that span of control for public services is very far and barely felt by some of the community in Natuna Regency, especially community in distant islands who struggle with the difficult natural condition of South China Sea. Geographically, Natuna Regency lies between $1^{\circ} 16^{\prime}$ North latitude to $7^{\circ} 19^{\prime}$ North latitude and $105^{\circ} 00^{\prime}$ East longitude and $110^{\circ} 00^{\prime}$ East longitude. Natuna Regency has area size of 264,198.37 $\mathrm{km}^{2}$, consisting mostly of water area, with area of $262,197.07 \mathrm{~km}^{2}$, and the rest is islands, with area of $2001.3 \mathrm{~km}^{2}$. Population size of Natuna Regency in 2016 is 73.470 people. Natuna Regency is one of 183 regions in Indonesia categorized as UOF (Underdeveloped, Outermost, and Frontmost), where administratively this region shares borders with:

North Side: Vietnam and Cambodia.

South Side: Bintan Island.

East Side: East Malaysia and West Kalimantan.

West Side: Anambas Islands Regency.

Natuna regency has 154 islands, with 27 islands (17.53\%) are inhabited and the rests (127 islands) are not inhabited yet. Two largest islands are Bunguran 
Island and Serasan Island. These islands are divided into 2 groups:

$>$ Natuna Islands, consisting of islands in Bunguran, Sedanau, Midai, Pulau Laut, and Pulau Tiga.

Serasan Islands, consisting of islands in Serasan, Subi Besar, and Subi Kecil [5].

Climate in Natuna, which is part of Riau Islands Province, is tropical and very susceptible by changes of wind direction. Dry season usually occurs on March to July. Average rainfall is 193.2 millimeters with average humidity of $90.4 \%$ and average temperature of $25.8^{\circ} \mathrm{C}$. The exploitation of sea potential is minimum due to there is only six months of friendly season. This has great influence on fishery business in Riau Islands Province, both in fishing and in cultivation. While in the rests, when North Wind comes, the sea around Natuna becomes savage and fishermen prefer to farm for living. Natuna Regency (Figure 1) consists of 15 districts, 70 villages and 6 sub-districts, with characteristics of islands area and very far span of control between some districts to capital of regency causing great difficulty for administration of government, especially in providing excellent public services [6].

Aspiration of Natuna community expecting formation/creation of new autonomous region needs to be responded by authorized parties, mainly Local Government and Regional House of Representatives $(D P R D)$. This is in line with explanation of Law No. 23 of 2014 on Local Government that implementation of regional autonomy should always be oriented to improvement of social welfare by considering public interests and aspiration. The question is whether this aspiration can assure the improvement of public services and social welfare in $\mathrm{Na}$ tuna Regency.

It can only be answered objectively if firstly there is study on existing potentials and problems in Natuna, and then followed by exploring public aspiration and opinion through direct interview and questionnaire. Formation of Natuna Regency should be carried out if it impacts positively on better and more evenly distribution of development and public services.

The study on the possibility of formation of Natuna Regency should be in line with prevailing laws and regulations, of which Law No. 22 of 1999 had been replaced by Law No. 32 of 2004, and Law No. 32 of 2004 has also been replaced by Law No. 23 of 2014 on Local Government. In Law No. 22 of 1999 and Law No. 32 of 2004, it was stated that creation of region can take form of merging of regions or adjacent division of regions or formation of one region into two or more regions. One procedure for creation/formation of region according to the rule is that there is political will of local government and concerned society. Law No. 22 of 1999 had derivative regulation on the creation of autonomous region, namely Government Regulation No. 129 of 2000 on Requirements for Creation and Criteria for Formation, Elimination and Merging of Regions. In this GR, there was at least 7 criteria, 9 indicators and 43 sub-indicators that become requirements for formation of region. In this Law No. 129 of 2000, it was also stated that formation of region is aimed mainly to improve social welfare [7]. 


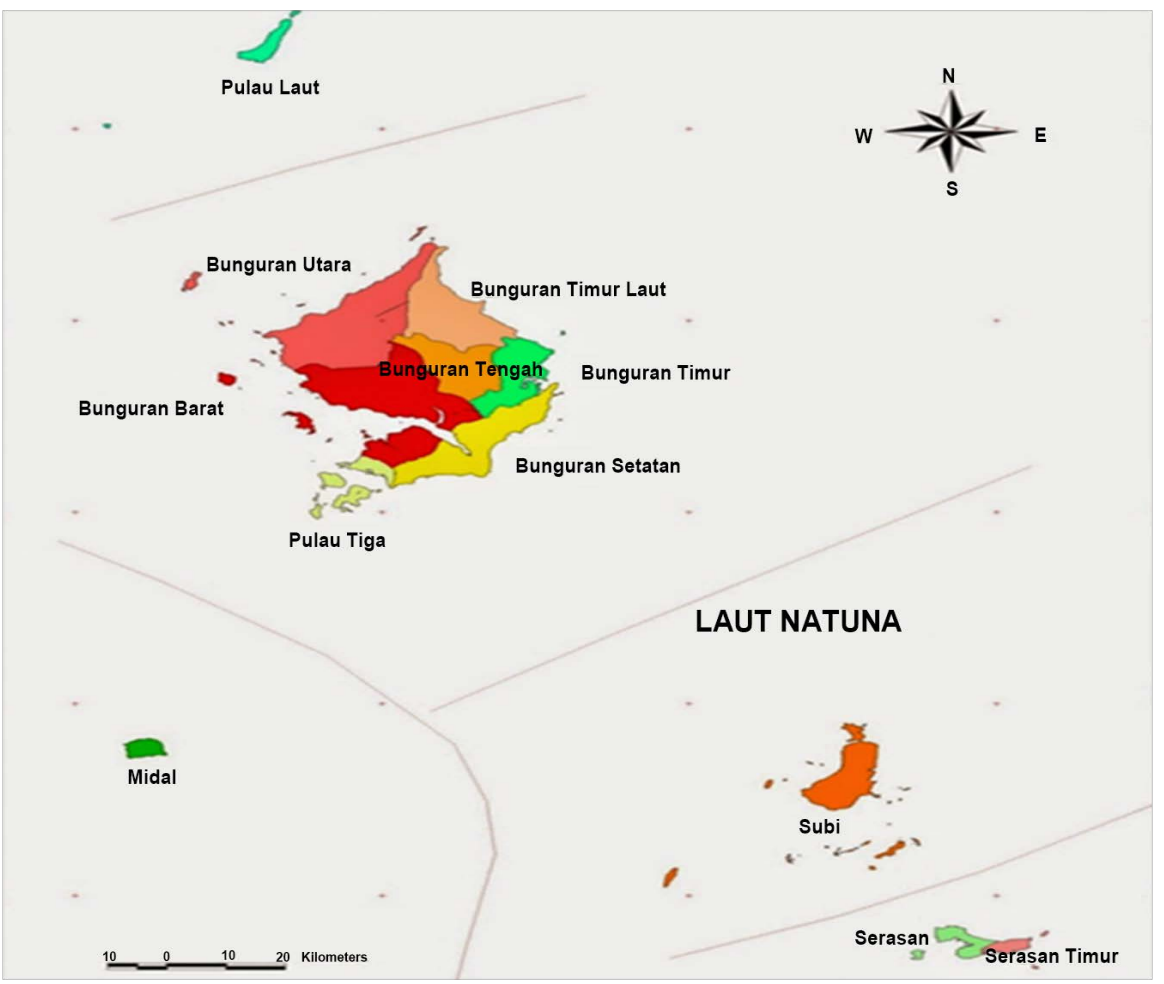

Figure 1. Map of administrative area of natuna regency. (Source: natuna regency in number 2015).

And then, in Law No. 32 of 2004 in lieu of Law No. 22 of 2000, it regulates creation of region and special territory. As explanation of those laws and regulations, government has issued Government Regulation No. 78 of 2007 on Creation, Elimination and Merging of Regions in lieu of Government Regulation No. 129 of 2000. According to it, requirements for creation of autonomous region should at least qualify administrative, technical and territorial physical requirements. Administrative requirement for province includes approval by $D P R D$ of regencies/cities and regents/mayors in the area of proposed province, approval by $D P R D$ of parent province and the governor, and also recommendation from Minister of Home Affairs. For creation of autonomous region of regency/city, it includes approval by $D P R D$ of regencies/cities, approval by regents/mayors, approval by governor, approval by $D P R D$ of province, and recommendation from governor.

Technical requirement serving as basis for creation of formation includes economic capability, potential of the region, socio-culture, socio-politics, demography, area size, defense and security, social welfare, and span of control that enable the implementation of regional autonomy, and physical requirement includes at least 5 (five) regencies/cities for creation of province and at least 5 (five) districts for creation of regency and 4 (four) districts for creation of city, location of proposed capital, availability of administrative facilities and infrastructures. In addition, in explanation of article 4 clause (4) Law No. 32 of 2004, it is stated that formation of a region into 2 (two) or more regions can be done 
after reaching minimum age of governmental administration, of which for province is 10 years and for regency/city is 7 years [8].

Furthermore, for now Government has issued Law No. 23 of 2014 in lieu of Law No. 32 of 2004 on Local Government, and also in awaiting for approval of Draft Government Regulation (DGR) on Regional Reorganization in lieu of GR No. 78 of 2007. In Law No. 23 of 2014 and DGR on Regional Reorganization, it is stated that formation of region is included in context of regional reorganization consisting of Creation of Region and Readjustment of Region based on consideration of NATIONAL STRATEGIC INTERESTS. Furthermore, it is also explained that Creation of Region takes form of formation of region and merging of regions. Formation of region can take form of dividing of province or regency/city into two or more new regions or merging of regions or adjacent division of regions within 1 (one) province into one new region. Formation of region is implemented through phase of Preparation Region of Province or Preparation Region Regency/City by qualifying basic and administrative requirements, and for creation of Preparation region of city, in addition to qualifying basic and administrative requirements, it should also has urban characteristic of $50 \%$ (fifty percent) or more of its population working outside primary sectors. Basic requirement for creation of preparation region of aforementioned includes:

A) Territorial basic requirement, including:

a) Minimum area size;

b) Minimum population size;

c) Territorial borders;

d) Territorial coverage; and

e) Minimum age of province, regency/city, and district.

Territorial basic requirement is regulated in more detail in Regulation of Minister Regulation, which differentiate requirements of minimum area size and population size according to grouping of island or islands defined by territorial borders with coordinates in basic map. In general, territorial coverage for creation of region includes:

a) At least 5 (five) regencies/cities for creation of province;

b) At least 5 (five) districts for creation of regency; and

c) At least 4 (four) districts for creation of city.

It also differentiates territorial coverage of preparation region consisting of islands of which territorial coverage should detail name of islands. In addition to territorial coverage, creation of autonomous region should also comply with regulation of minimum age of governmental administration, including:

a) Minimum age of province is 10 (ten) years and regency/city is 7 (seven) years, from the date of the creation; and

b) Minimum age of district under territorial coverage of regency/city is 5 (five) years, from the date of the creation [9].

B) Basic requirements of Regional capacity

Basic requirements of regional capacity is based on parameter: 
1) Geography, including:

a) Location of capital;

b) Hydrographic; and

c) Disaster-proneness.

2) Demograhy, including:

a) Quality of human resources; and

b) Distribution of population.

3) Security, including:

a) General criminal acts; and

b) Social conflicts.

4) Social-politics, local custom, and traditions, including:

a) Public participation in general election;

b) Social cohesiveness; and

c) Social organization.

5) Economic potential, including:

a) Economic growth; and

b) Regional core competence.

6) Regional financial, including:

a) Capacity of parent region's local own source revenue;

b) Potential of proposed preparation region's local own source revenue; and

c) Regional financial and asset management.

7) Capability of governmental administration, including:

a) Accessibility of basic service of education;

b) Accessibility of basic service of health;

c) Accessibility of basic service of infrastructures;

d) Number of state civil apparatus in parent region; and

e) Draft spatial planning for preparation region.

Based on elaboration above, Natuna Regency will implement regional reorganization by creation of new autonomous region (formation of region), however, it is required to firstly study its regional potential, by measurement and evaluation of variables or criteria of regional potential to determine whether it is possible or not to create new autonomous region in Natuna Regency according to criteria stated in GR No. 129 of 2000 derivative of Law No. 22 of 1999, GR No. 78 of 2007 derivative of Law No. 32 of 2004, and DGR on Regional Reorganization derivative of Law No. 23 of 2014 [10].

\section{Problem Statement}

Reorganization/Creation of an autonomous region should at least qualify basic and administrative requirements, either requirements according to GR No. 129 of 2000, requirements according to GR No. 78 of 2007, and requirements according to DGR on Regional Reorganization in lieu of GR No. 78 of 2007, following the issuance of Law No. 23 of 2014 in lieu of Law No. 32 of 2004 on Local Government. Then, problem statement in Creation of New Autonomous Region 
of Natuna Regency can be formulated as follows:

1) What is description on capability level of Natuna Regency in the administration of local government?

2) How is design of possibility on the creation of new autonomous region based on criteria of formation of region serving as basis in determining the recommended policy of whether or not it is possible to create new autonomous region in Natuna Regency, with reference to GR No. 129 of 2000, GR No. 78 of 2007, and DGR on Regional Reorganization 2016?

\section{Theoretical Framework}

Theoretical framework on creation of new autonomous region in this paper is carried out with criteria:

a) According to Law No. 22 of 1999 and GR No. 129 of 2000

Taking close look on Chapter III of Law No. 22 of 1999, it appears that in order to exploit capability of the region to implement regional autonomy, it is possible to make policy at the same level of law for creation, formation, elimination and merging of autonomous regions. Correspondingly, policy rule of Government Regulation No. 129 of 2000 have also been issued, in which regulates the requirement for creation and criteria of formation, elimination and merging of regions [11]. In Article 11 and Article 15 of said GR, it also regulates on procedure for measurement and evaluation of creation, formation, elimination and merging of regions. Measurement and evaluation are conducted towards capability level of the region, represented as indicators and sub-indicators of variables/criteria of economic capability, regional potential, socio-culture, socio-politics, population size, area size and other considerations that may enable the implementation of regional autonomy. Result of measurement is particular total score of capability level of potential which serve as basis for evaluation of whether a region is adequate or not for formation. Evaluation on the capability level of region for formation is evaluation on potential of all districts to have description on the capability of proposed autonomous city and proposed parent regency [12].

Result of evaluation can be categorized into 3 (three) levels, Qualified, Qualified with Condition and Unqualified, which serve as recommendation for policy:

1) If proposed autonomous city is qualified and proposed parent regency is qualified, then action to be taken is to recommend the formation of autonomous region/creation of new autonomous city;

2) If proposed autonomous city and proposed autonomous regency are qualified with condition, then action to be taken is to implement the formation of autonomous region/creation of autonomous city followed by promotion and development of regional potential within 5 years period and extended time limit of 5 years for evaluation. If they remain unqualified within the time limit, the proposed autonomous city can be re-suggested for merging with proposed parent regency. 
3) If both are or any of proposed autonomous city and proposed parent regency is unqualified, then action to be taken is to conduct promotion and development of potential to become categorized as qualified with condition [10].

For more detailed theoretical framework for creation of autonomous city in Natuna Regency, see chart below (Figure 2).

b) According to Law No. 32 of 2004 and GR No. 78 of 2007

Taking close look Law No. 32 of 2004, Chapter III on Creation of Region and Special Region, especially Article 4 clause (1), it appears that in order to exploit capability of the region to implement regional autonomy, it is possible to make policy at the same level of law for creation, formation, elimination and merging of autonomous regions [13]. Policy on guideline that regulate requirement for creation, elimination and merging of region is stated in Government Regulation No. 78 of 2007 Measurement and evaluation are conducted towards capability level of the region, represented as indicators and sub-indicators of factors of demography, economic capability, regional potential, financial capability, socio-culture, socio-politics, area size, security and defense, welfare rates and span of control [14].

Result of measurement is particular total score of capability level of region which serve as basis for evaluation of whether a region is adequate or not for formation. Evaluation of capability level of region for formation is evaluation towards potential of district. Result of evaluation can be categorized into 5 (five) levels: Very Capable, Capable, Less Capable, Incapable and Very Incapable. Result of evaluation serves as recommendation for policy as follows:

1) A region is recommended as autonomous region if parent region and proposed formed region have total score under category of very capable (420 - 500) or capable (340 - 419), and total score for factors of demography by $80-100$, economic capability by $60-75$, regional potential by $60-75$ and financial capability by $60-75$.

2) Recommendation for creation of region is declined if parent region or proposed formed region have total score under category of less capable, incapable, and very incapable to administer regional autonomy, or total score for factors of demography by less than 80 , economic capability by less than 60 , regional potential by less than 60 , or financial capability by less than 60 [10].

For more detailed theoretical framework for formation of Natuna Regency according to GR No. 78 of 2007, see chart below (Figure 3).

c) According to Law No. 23 of 2014, and DGR on Regional Reorganization 2017

According Law No. 23 of 2014 on Local Government, in decentralization, there is Regional Reorganization. Regional Reorganization can take form of Creation of Region and Readjustment of Region [15]. Creation of Region basically is meant to achieve effectiveness in administration of Local Government, to accelerate the improvement of social welfare and quality of public services, to increase the quality of governance, to improve national and local competitiveness, 


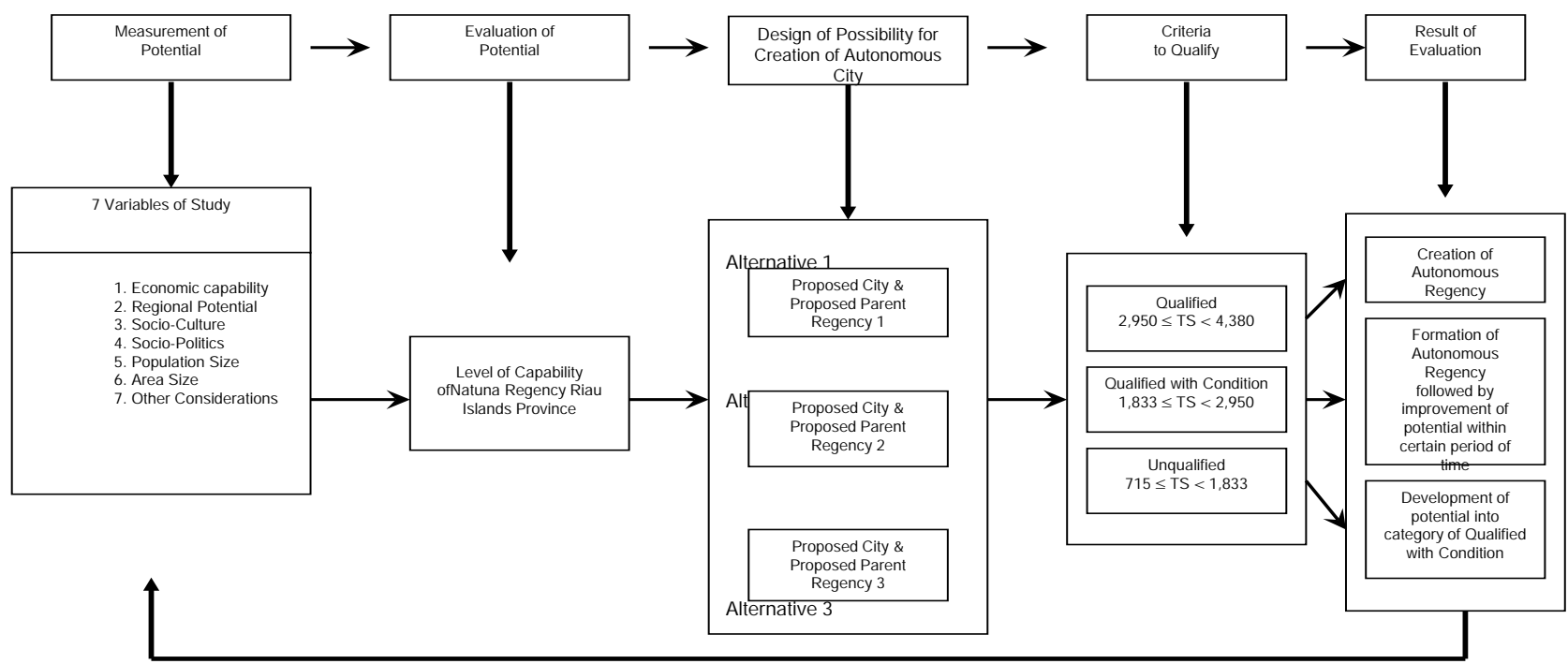

Figure 2. Theoretical framework for creation of new autonomous region of natuna regency (GR No. 129 of 2000).

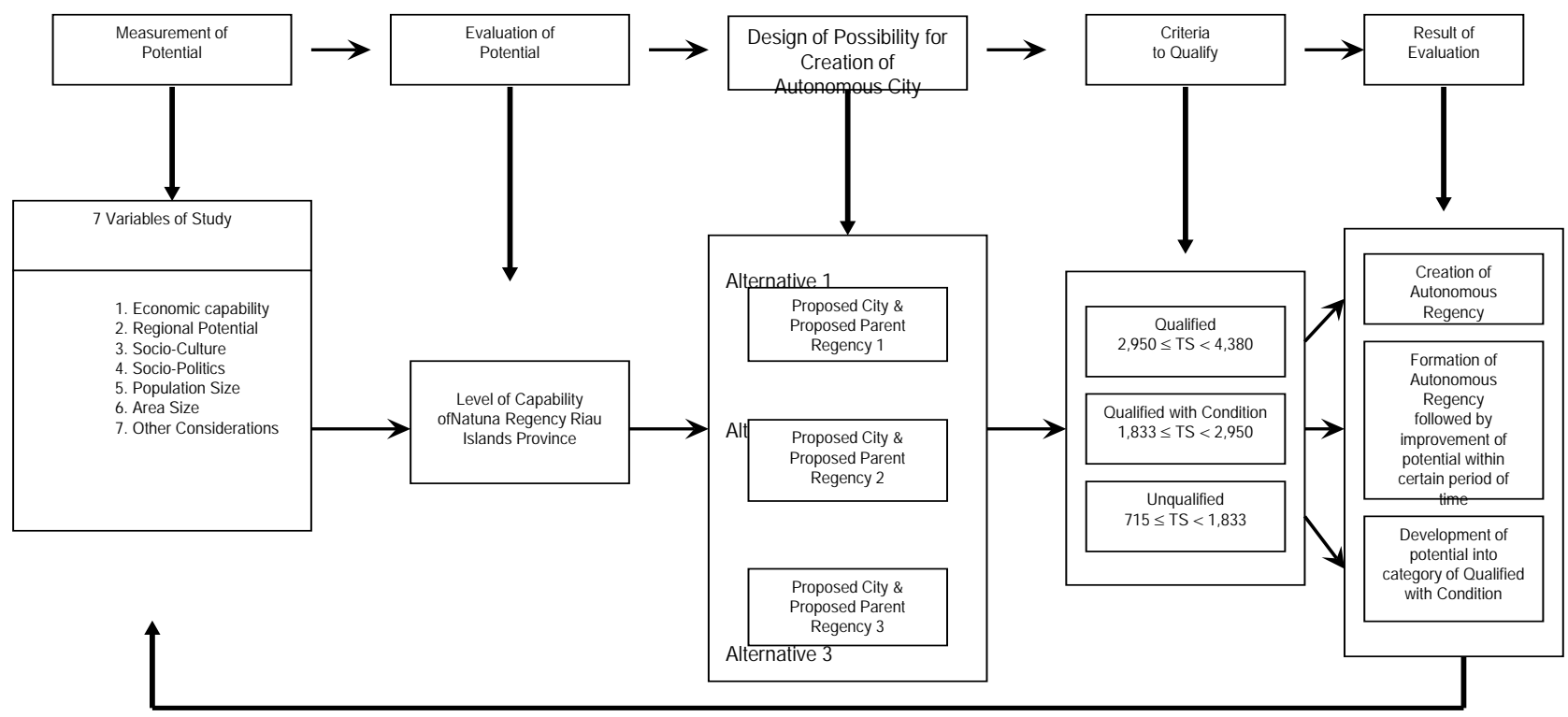

Figure 3. Theoretical framework for creation of new autonomous region of natuna regency (GR No. 78 of 2007).

to preserve uniqueness of local custom, tradition, and culture, and to find solution for social conflicts [16].

Creation of province and regency/city can be by Formation of Region and Merging of Regions. Formation of region can take form of dividing of province or regency/city into two or more new regions or merging of regions or adjacent division of regions 1 (one) new region. Creation of Region is preceded by Preparation Region stage in 3 (three) years. Creation of Preparation Region should qualify 2 (two) requirements: a) basic requirement; and b) administrative requirement. Basic requirements include territorial basic requirements and regional capacity basic requirements [17].

Preparation Region is headed by Head of Preparation Region appointed from qualified civil servant. Preparation Region receives administrative and financial 
affairs in order to administer government. Central Government provides stewardship and supervision towards Preparation Region in preparation period. Supervision towards Preparation Region is also conducted by $D P R D$ and Regional Representatives Council $(D P D)$ and community. Towards Preparation Region, evaluation in the first and second year as well as final evaluation are conducted. Final evaluation is conducted in preparation period at least 3 (three) months before the end of 3 (three) years preparation period. If result final evaluation shows that the Preparation Region is unqualified, its status is returned to Parent region. If the Preparation Region is qualified, then it shall be formed as Region by Law [18].

Merging of Regions can be by merging of 2 (two) or more adjacent regencies/cities in 1 (one) province into new regency/city, and merging of 2 (two) or more adjacent provinces into new province. Merging of regions is conducted based on agreement of concerned regions or result of evaluation by Central Government. Merging of Regions based on agreement of concerned regions should qualify administrative requirements and regional capacity basic requirements. It can also be conducted in case of one or several regions is/are unable to administer regional autonomy based on result of evaluation of Central Government. For Regional Reorganization, Central Government can also conduct Readjustment of Region. Readjustment of region can be by change of regional borders, name change of region, naming of and name change of earth surface, relocation of capital, and/or name change of capital. Change of regional borders is regulated by Law. Name change of region, naming of and name change of earth surface, relocation of capital, and name change of capital city are regulated by Government Regulation.

Creation of region can also be conducted by Central Government with consideration of national strategic interests, which applies to borderlands, outermost islands, and certain regions for maintaining of interests and sovereignty of the Unitary State of the Republic of Indonesia. Creation of Region with consideration of national strategic interests should have territorial coverage with clear borders and should consider parameter of security and defense, economic potential, and other parameter that consolidate sovereignty of the Unitary State of the Republic of Indonesia. Creation of Region with consideration of national strategic interests should also be conducted through phase of Preparation Region of province or regency/city for at least 5 (five) years period.

In addition to creation of Preparation Region, Central Government can also conduct Readjustment of region with consideration of national strategic interests by change of regional borders and relocation of capital city. Change of regional borders is regulated by Law. Relocation of capital city is regulated by Government Regulation. With many ways and requirements and procedure, it is expected that new region can grow, develop, and administer regional autonomy for optimum public services in order to accelerate the achievement of social welfare and to consolidate integrity of the Unitary State of the Republic of Indonesia. Regional Reorganization is expected to make region more capable to ad- 
minister regional autonomy, so that the purpose of Regional Reorganization can be achieved [10].

For more detailed theoretical framework for formation of Natuna Regency according to DGR on Regional Reorganization 2017 as follow-up of Law No. 23 of 2014, see chart below (Figure 4).

\section{Research Method}

Population of local government organization in this study is all districts in Natuna Regency or 15 (fifteen) districts and 70 villages and 6 sub-villages. This study was made not long after the enactment of Law No. 23 of 2014 on Local Government in lieu of Law No. 32 of 2004 on Local Government, by which enactment should be followed by the issuance of new Government Regulation, which is still in form of Draft Government Regulation (DRG) on Regional Reorganization. This study uses two Government Regulations and one DRG on Regional Reorganization, i.e. 19 (nineteen) variables according to Government Regulation No. 129 of 2000, 11 (eleven) variables according to Government Regulation No. 78 of 2007 on Creation, Elimination and Merging of Regions and Territorial Basic Requirements, Regional Capacity Basic Requirements and Administrative Requirements according to Law No. 23 of 2014, and DGR on Regional Reorganization 2017. Indicators and sub-indicators of the regulations is shown in Tables 1-3.

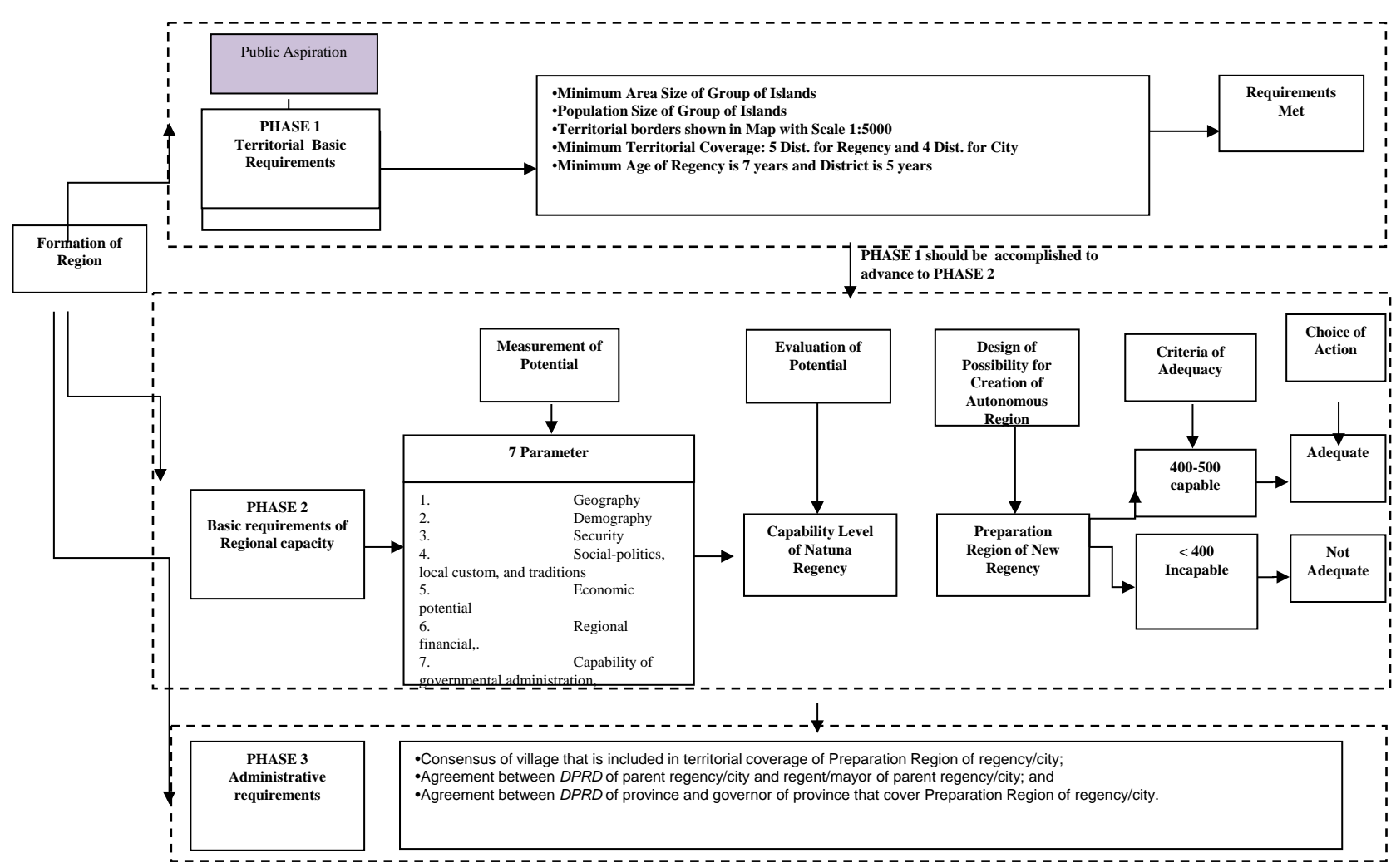

Figure 4. Theoretical framework for creation of new autonomous region of natuna regency (Law No. 23 of 2014, and DGR on Regional Reorganization 2017). 
Table 1. Criteria, Indicators and sub-indicators according to GR. 129 of 2000.

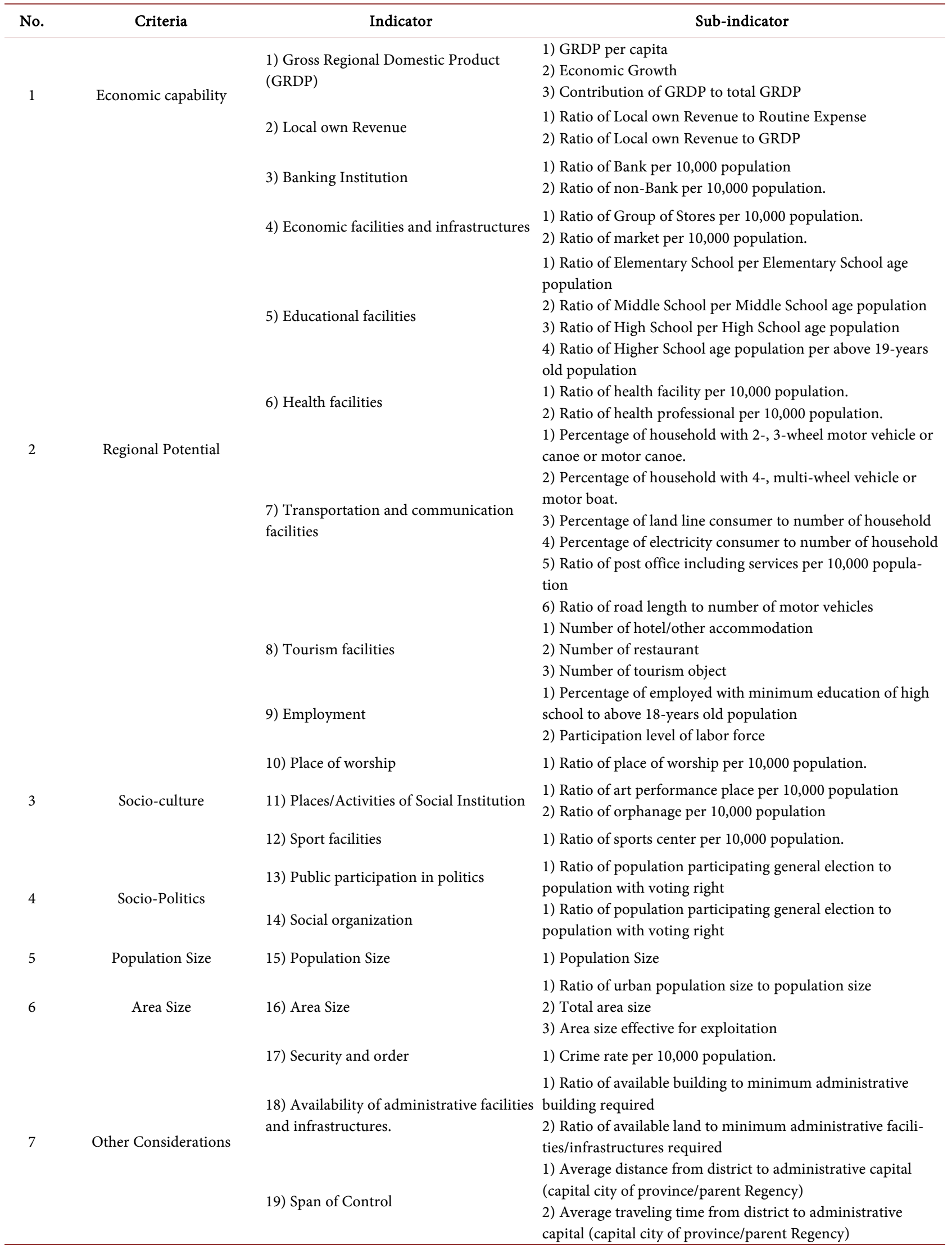


Table 2. Indicators and sub-indicators according to GR. 78 of 2007.

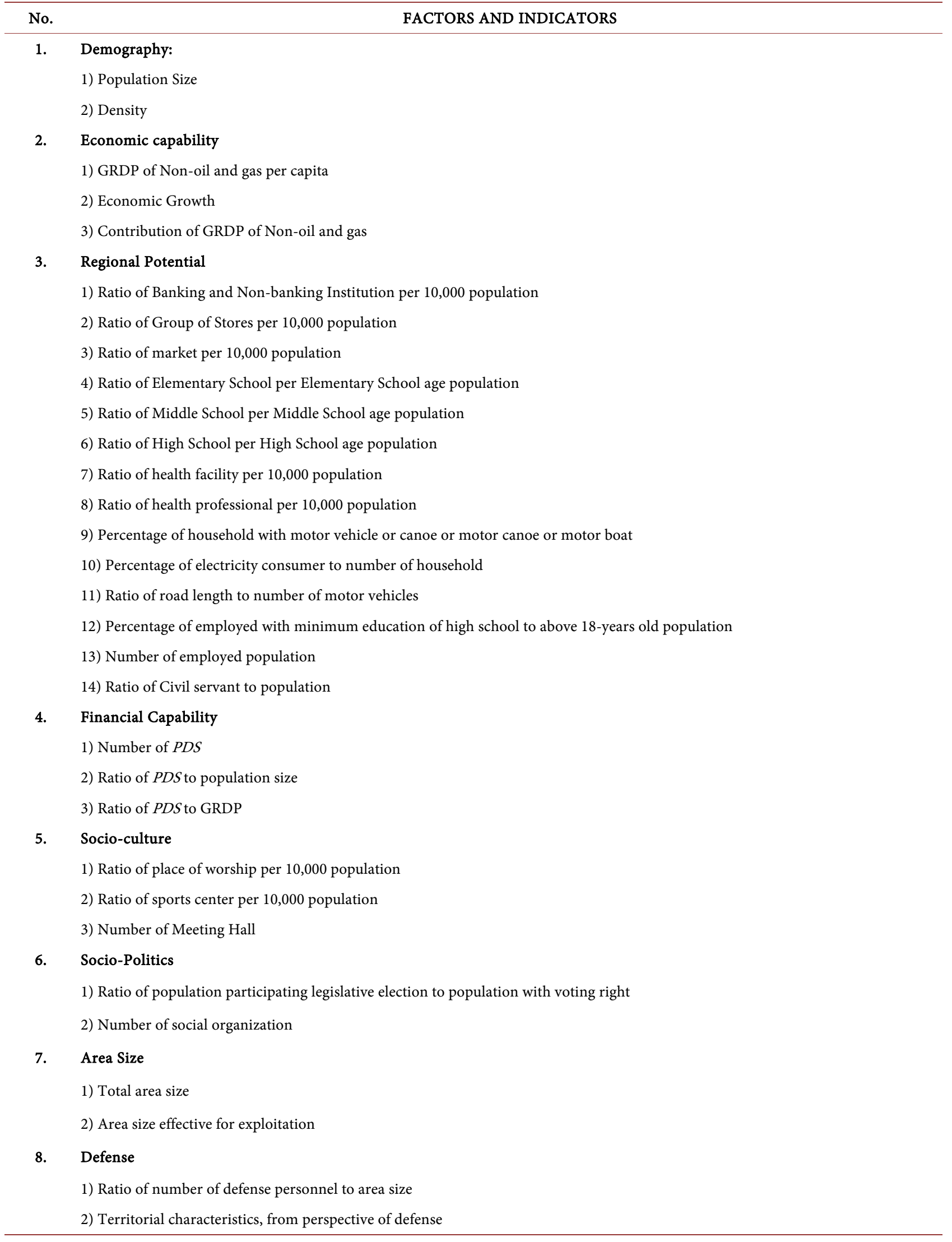




\section{Continued}

9. Security

1) Ratio of number of Security personnel to area size

10 Social welfare rate

1) Human Development Index

11 Span of Control

1) Average distance from district to administrative capital

2) Average travelling time from district to administrative capital

Table 3. Criteria, Indicators and sub-indicators according to GR No. 23 of 2014 and DGR on regional reorganization.

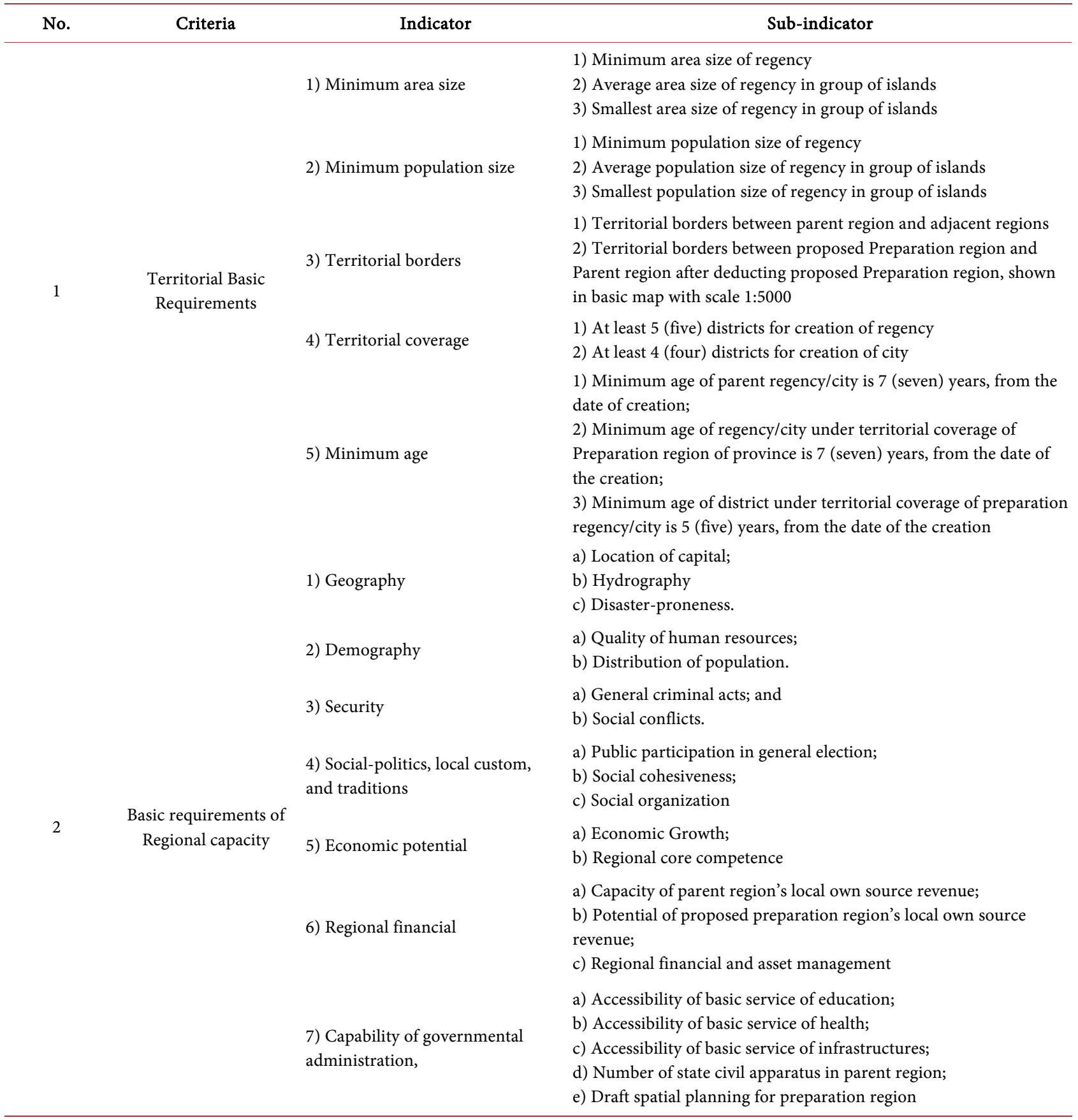


1) Consensus of village that is included in territorial coverage of Minutes of Agreement, at least containing:

a) Agreement for Territorial coverage of Preparation region of regency/city;

Preparation Region of regency/city; b) Agreement on name of Preparation region of regency/city;

c) Agreement on proposed capital city of Preparation region

Minutes of agreement between $D P R D$ of parent regency/city and regent/mayor of parent regency/city, at least containing:

a) Creation of Preparation region of regency/city;

b) Territorial coverage of Preparation region of regency/city;

c) Name of Preparation region of regency/city;

2) Agreement between $D P R D$ of parent regency/city and regent/mayor of parent regency/city;

d) Location of capital of Preparation region of regency by showing district appointed as location of capital and stating its coordinates as shown in map attached;

e) Financial support from parent regency/city in the government administration of Preparation region of regency/city for 3 (three) years period, straight from the date of Preparation region is officially announced; and

f) Providing the personnel, facilities and infrastructures, and documents needed by Preparation region

Minutes of agreement signed by Speaker of DPRD of province and governor of province that cover Preparation Region of regency/city, at least containing:

a) Creation of Preparation region of regency/city;

3) Agreement between $D P R D$ of b) Territorial coverage of Preparation region of regency/city; province and governor of province that cover Preparation Region of regency/city. c) Name of Preparation region of regency/city;

d) Location of capital of Preparation region of regency by showing district appointed as location of capital and stating its coordinates as shown in map attached;

e) Grant for government administration of Preparation region of regency/city for 3 (three) years period, from the date of Preparation region is officially announced

a) Technique of Data Processing according to GR No. 129 of 2000

Category of evaluation is based on particular scale and determined according to classification of qualified, qualified with condition, and unqualified based on representative particular total score, by which category of evaluation serves as basis to choose whether or not to implement formation of autonomous region and exploitation of regional potential. Evaluation method used is scoring system with 3 (three) method types as follows:

\section{- Method A (Method of Mean)}

Method that compare value of each district towards average value of all districts. The closer it is to weighted average value of parent region in general, the greater the score is. Each sub-indicator has the lowest score of 1 and highest score of 6. Method A is used for sub-indicator 1, 2 and 3. For scoring, the steps are:

1) Define average score of sub-indicators of all districts;

2) Define score index of sub-indicators in each district (divide score of sub-indicators of each district with average score of all districts and multiplied with 100) and;

3) Define index class for scoring with assumption that score 5 to 6 are score 
above average $(\geq 100)$, and score 1 to 4 is score below average $\{(100$-lowest score $)$ divided with 4 \}.

\section{- Method B (Method of Distribution).}

Method of average that consider data distribution. Score calculation with this method is adjusted according to skewness and kurtosis of data distribution curve. Each sub-indicator has the lowest score of 1 and highest score of 6 . Method B is used for sub-indicator 4 to 24 and 36 to 43 . For scoring, the steps are:

1) Calculate the mean, standard deviation, and coefficient of kurtosis;

2) Calculate limit 3 (value $3 \times$ kurtosis $\times$ standard deviation), and limit 2 (value $2 \times$ kurtosis $\times$ standard deviation) and limit 1 (value $1 \times$ kurtosis $\times$ standard deviation) and;

3) Determine index class for scoring:

If indicator value $>$ mean + limit 2 , the score is 6 ;

If mean + limit $2 \leq$ indicator value $<$ mean + limit 1 , the score is 5 ;

If mean + limit $1 \leq$ indicator value $<$ mean, the score is 4 ;

$>$ If mean $\leq$ indicator value $<$ mean - limit 1 , the score is 3 ;

$>$ If mean - limit $1 \leq$ indicator value $<$ mean - limit 2 , the score is 2 ;

$>$ If indicator value $\leq$ mean - limit 2 , the score is 1 .

\section{- Method C (Method of Quota)}

Method that uses certain number for scoring. The closer it is to number of quota, the higher the score. This method is used for data on population size and only for urban area. Metode $\mathbf{C}$ is used for sub-indicator 35. For scoring, the steps are:

1) Determine size of the quota for sub-indicator of population size with assumption of 10,000 people;

2) Define index class for scoring with assumption that score 5 to 6 are score above average ( $\geq 10,000$ people), and score 1 to 4 is score below average $\{(10,000$ people -lowest score) divided with 4 \}.

Assumption used in valuing is that every variable or criteria has distinctive value according to its role in the administration of regional autonomy in regency/city. Value for economic capability is 25, regional potential is 20, socio-culture is 10 , socio-politics is 10 , population size is 15 , area size is 15 , and other considerations is 5 . Thus total of all values is 100. Minimum passing score is accumulated score of sub-indicators in each variable/group of criteria multiplied by score above average for each variable or group of criteria multiplied by value for each group of indicators. Calculation of minimum and maximum total score of each and every variable can be seen in Table 4 as follows.

Minimum passing score is accumulated score of sub-indicators in each variable/group of criteria multiplied by score above average for each variable or group of criteria multiplied by value for each group of indicators. Assumption used is that score above average for each variable is 4 , except 3 sub-indicators of variable of economic capability and variable of population size which is 5 . For more detail, see Table 5 . 
Table 4. Maximum and minimum score of variables/criteria.

\begin{tabular}{lcccccc}
\hline $\begin{array}{c}\text { VARIABLE/ } \\
\text { CRITERIA }\end{array}$ & $\begin{array}{c}\text { TOTAL OF } \\
\text { SUB-INDICATOR }\end{array}$ & VALUE & $\begin{array}{c}\text { MAX } \\
\text { SCORE }\end{array}$ & $\begin{array}{c}\text { MIN } \\
\text { SCORE }\end{array}$ & $\begin{array}{c}\text { TOTAL } \\
\text { MAX } \\
\text { SCORE }\end{array}$ & $\begin{array}{c}\text { TOTAL } \\
\text { MIN } \\
\text { SCORE }\end{array}$ \\
\hline 1) Economic capability & 5 & 25 & 30 & 5 & 750 & 125 \\
2) Regional Potential & 23 & 20 & 138 & 23 & 2,760 & 460 \\
3) Socio-culture & 4 & 10 & 24 & 4 & 240 & 40 \\
4) Socio-Politics & 2 & 10 & 12 & 2 & 120 & 20 \\
5) Population Size & 1 & 15 & 6 & 1 & 90 & 15 \\
6) Area Size & 2 & 15 & 12 & 2 & 180 & 30 \\
7) Other Considerations & 5 & 5 & 30 & 5 & 150 & 25 \\
\multicolumn{1}{c}{ TOTAL } & $\mathbf{4 2}$ & $\mathbf{1 0 0}$ & $\mathbf{2 5 2}$ & $\mathbf{4 2}$ & $\mathbf{4 2 9 0}$ & $\mathbf{7 1 5}$ \\
\hline
\end{tabular}

Table 5. Variable/criteria above average according to GR No. 129 of 2000.

\begin{tabular}{lcccc}
\hline No. & Variable/Criteria & Calculation & $\begin{array}{c}\text { Score Above } \\
\text { Average }\end{array}$ \\
\hline 1. & Economic capability & $3 \times 5 \times 25=375$ & $=$ & 575 \\
2. & $2 \times 4 \times 25=200$ & $=$ & 1.840 \\
3. & Regional Potential & $23 \times 4 \times 20$ & $=$ & 160 \\
4. & Socio-culture & $4 \times 4 \times 10$ & $=$ & 80 \\
5. & Socio-Politics & $2 \times 4 \times 10$ & $=$ & 75 \\
6. & Population Size & $1 \times 5 \times 15$ & $=$ & 180 \\
7. & Area Size & $2 \times 4 \times 15$ & $=$ & 100 \\
& Other Considerations & $5 \times 4 \times 5$ & $=$ & 2.950 \\
\hline
\end{tabular}

According to Table 5, the score above average is 2950 . This means that a regency, either proposed parent regency and proposed formed regency, is declared qualified or capable to administer autonomy if the measurement result in

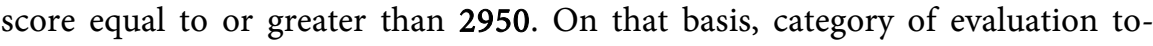
wards regional capability can be defined as stated in Table 6 .

As comparison, measurement and evaluation are also conducted by manual/guidelines for creation, formation, elimination and merging of autonomous regions (GR129/2000) which results from cooperation between State Minister of Regional Autonomy, Statistics Indonesia (BPS), National Development Planning Agency (Bappenas), Department of Finance and Department of Home Affairs. Assumption used in this manual is that score above average for each variable is 3 , except 3 sub-indicators of variable of economic capability and variable of population size which is 4 . For more detail, see Table 7.

According to Table 7, the score above average is 2235 . This means that a regency, either proposed parent regency and proposed formed regency, is declared qualified or capable to administer autonomy if the measurement result in score equal to or greater than 2235 , and qualified with condition if the score is 
Table 6. Category and action taken.

\begin{tabular}{|c|c|c|}
\hline No & Inverval of Total Score & Category of Evaluation \\
\hline 1. & $2950 \leq \mathrm{TS}<4290$ & - QUALIFIEF/CAPABLE \\
\hline 2. & $1833 \leq \mathrm{TS}<2950$ & - QUALIFIED WITH CONDITION \\
\hline 3. & $715 \leq \mathrm{TS}<1833$ & - UNQUALIFIED/INCAPABLE \\
\hline
\end{tabular}

Table 7. Variable/criteria above average according dept of finance, bappenas, bps, and dept of home affairs.

\begin{tabular}{cccc}
\hline No & Variable/Criteria & Calculation & Score Above Average \\
\hline 1. & Economic capability & $3 \times 4 \times 25=300$ & $=450$ \\
2. & Regional Potential & $2 \times 3 \times 25=150$ & $=1380$ \\
3. & Socio-culture & $4 \times 3 \times 10$ & $=120$ \\
4. & Socio-Politics & $2 \times 3 \times 10$ & $=60$ \\
5. & Population Size & $1 \times 4 \times 15$ & $=60$ \\
6. & Area Size & $2 \times 3 \times 15$ & $=90$ \\
7. & $5 \times 3 \times$ & $=75$ \\
& Ther Considerations & & $=2235$ \\
\hline
\end{tabular}

less than 2235. To be clear, all calculations and statistic analysis in this paper are aided by computer with program SPSS for MS Windows Release 10.01, Microsoft Excel and Mikrostatistik.

b) 3.5.2 Technique of Data Processing according to GR No. 78 of 2007

Qualitative data is analyzed by content and depth approach to interpret phenomena of demography, economic capability, regional potential, financial capability, socio-culture, socio-politics, area size, security and defense, and span of control. How to accommodate the qualitative analysis is by stimulating various inclination of qualitative responses from respondents on those phenomena.

From list of open-end structured questions, complemented with compilation of in-depth interviews and field observation, the variables are compiled into structured file. However, some of the qualitative data are renovated into quantitative data through non-parametric process.

As for quantitative data, it is categorized, classified and processed as basis for measurement and analysis to provide explanation and evaluation on the strengths and weaknesses of variables of economic capability, regional potential, socio-culture, population size, area size, and other considerations in order to encourage regional capability in administration of regional autonomy.

Category of evaluation is based on particular scale and determined according to classification of very capable, capable, less capable, incapable and very incapable based on representative particular total score, by which category of evaluation serves as basis to choose whether or not to implement formation of autonomous region and exploitation of regional potential. 
Evaluation method used is scoring system with 2 (two) method types as follows:

\section{- Method 1 (Method of Mean)}

It is a method that compare value of each proposed region and parent region towards average value of all regions around. The higher the value of proposed region and parent region (if formed) towards average value, the higher the score is. Method 1 is used to calculate value of indicators 2 to 28 and 30 to 34 .

\section{- Method 2 (Method of Quota)}

It is a method that uses certain number as quota for scoring proposed region and parent region. Method 2 is specifically used for indicator 1, population size.

Each indicator has score with scale 1 - 5, average comparing value and amount of quota as basis for scoring. Score 5 is given if value of the indicator is equal to or greater than average value, score 4 is given if value of the indicator is equal to or greater than $80 \%$ of average value, score 3 is given if value of the indicator is equal to or greater than $60 \%$ of average value, score 2 is given if value of the indicator is equal to or greater than $40 \%$ of average value, score 1 is given if value of the indicator is equal to or greater than $20 \%$ of average value.

Scoring for creation of province uses Comparing Province, creation of regency uses Comparing Regency, and creation of city uses Comparing City. Comparing Regency is regencies in the concerned province, and Comparing City is the similar cities (excluding the capital city of province) in the concerned province or province around it of at least 3 (three) cities. In terms of determining the comparing province, comparing regency and comparing city, provinces, regencies and cities that have very different indicator value (above 5 times of the lowest value), the values should be disregarded.

Especially for indicator of territorial characteristic (no. 31), scoring is based on characteristics shown in physical terrain of the proposed autonomous region (lands, or land and coast/sea, or islands, and position of whether or not the proposed autonomous region shares borders with other countries).

Scoring for indicator of territorial characteristic is measured with criteria as follows (Table 8).

Assumption used in valuing is that every factor and indicator of criteria has distinctive value according to its role in the creation of regional autonomy.

Minimum passing score is accumulated score of indicators in each factor of criteria multiplied by score above average for each variable or group of criteria multiplied by value for each group of indicators. Passing is determined by total score of factor with category (Table 9).

A region is recommended as autonomous region if parent region and proposed formed region have total score under category of very capable (420 - 500) or capable ( 340 - 419), and total score for factors of demography by $80-100$, economic capability by 60 - 75, regional potential by 60 - 75 and financial capability by 60 - 75 (Table 10). Recommendation for creation of region is declined if parent region or proposed formed region have total score under category of less capable, incapable, and very incapable to administer regional autonomy, 
Table 8. Criteria and score for territorial characteristic.

\begin{tabular}{crc}
\hline No. & Criteria & Score \\
\hline 1. & Sharing borders with other countries, terrain in form of islands & 5 \\
2. & Sharing borders with other countries, terrain in form of lands and coasts & 4 \\
3. & Sharing borders with other countries, terrain in form of lands & 3 \\
4. & Not sharing borders with other countries, terrain in form of lands and coasts, & 2 \\
\hline
\end{tabular}

Table 9. Valuing according to GR. No. 78 of 2007.

\begin{tabular}{|c|c|c|}
\hline No. & Factors and Indicators & Value \\
\hline \multirow[t]{3}{*}{1.} & Demography: & 20 \\
\hline & 1) Population Size & 15 \\
\hline & 2) Density & 5 \\
\hline \multirow[t]{4}{*}{2.} & Economic capability & 15 \\
\hline & 3) GRDP of Non-oil and gas per capita & 5 \\
\hline & 4) Economic Growth & 5 \\
\hline & 5) Contribution of GRDP of Non-oil and gas & 5 \\
\hline
\end{tabular}

3. Regional Potential

6) Ratio of Banking and Non-banking Institution per 10,000 population 2

7) Ratio of Group of Stores per 10,000 population 1

8) Ratio of market per 10,000 population 1

9) Ratio of Elementary School per Elementary School age population 1

10) Ratio of Middle School per Middle School age population 1

11) Ratio of High School per High School age population 1

12) Ratio of health facility per 10,000 population 1

13) Ratio of health professional per 10,000 population 1

14) Percentage of household with motor vehicle/canoe/motor canoe/motor 1 boat

15) Percentage of electricity consumer to number of household 1

16) Ratio of road length to number of motor vehicles 1

17) Percentage of employed with minimum education of high school to 1 above 18-years old population

18) Number of employed population 1

19) Ratio of Civil servant to population 1

4. Financial Capability 15

20) Number of $P D S$

21) Ratio of $P D S$ to population size $\quad 5$

22) Ratio of $P D S$ to GRDP

5. Socio-culture 5

23) Ratio of place of worship per 10.000 population 2

24) Ratio of sports facilities per 10,000 population 2

Population 
Continued

25) Number of Meeting Hall

6. Socio-Politics

26) Ratio of population participating in legislative election to population 3 with voting right

27) Number of social organization

7. Area Size

28)Total area size

29) Area size effective for exploitation

8. Defense
30) Ratio of number of defense personnel to area size
31) Territorial characteristics, from perspective of defense

9. Security

32) Ratio of number of Security personnel to area size

33) Human Development Index

34) Average distance from district to administrative capital

35) Average traveling time from district to administrative capital

Table 10. Category of evaluation.

\begin{tabular}{lccccc}
\hline \multicolumn{1}{r}{ Category } & & Score & & Explanation \\
\hline 1) Very Capable & 420 & to & 500 & Recommendation \\
2) Capable & 340 & to & 419 & Recommendation \\
3) Less Capable & 260 & to & 339 & Declined \\
4) Incapable & 180 & to & 259 & Declined \\
5) Very Incapable & 100 & to & 179 & Declined \\
\end{tabular}

or total score for factors of demography by less than 80 , economic capability by less than 60 , regional potential by less than 60 , or financial capability by less than 60. To be clear, all calculations and statistic analysis in this paper are aided by computer with program Microsoft Excel and Microstat.

c) Technique of Data Processing according to Law No. 23 of 2014 and DGR on Regional Reorganization

Technique of data processing according to Law No. 23 of 2014 and DGR on Regional Reorganization can be elaborated as follows:

\section{1) Territorial Basic Requirements}

\section{A) Minimum area size of proposed regency and proposed city}

Minimum area size for creation of proposed Preparation region of regency is calculated with formula below:

$$
W M=\frac{\bar{X} L D P+L D P K}{2}
$$


Explanation

$L W M=$ Minimum area size of regency.

$\bar{X} L D P=$ Average area size of regency in group of islands.

$L D P K=$ Smallest area size of regency in group of islands.

Minimum area size for creation of proposed Preparation region of City is calculated with formula below:

$$
L W M=\frac{\bar{X} L D P+L D P K}{2}
$$

Explanation

$L W M=$ minimum area size of city.

$\bar{X} L D P=$ Average area size of City in group of islands.

$L D P K=$ smallest area size of city

B) Minimum area size of proposed regency and proposed city

Minimum area size for creation of proposed Preparation region of regency is calculated with formula below:

$$
J P M=\frac{\bar{X} J P P+J P P K}{2}
$$

Explanation

$J P M=$ Minimum population size of regency.

$\bar{X} J P P=$ Average population size of regency in group of islands.

$J P P K=$ Smallest population size of regency in group of islands.

Minimum area size for creation of proposed Preparation region of City is calculated with formula below:

$$
J P M=\frac{\bar{X} J P P+J P P K}{2}
$$

Explanation

$J P M=$ minimum population size of city.

$\bar{X} J P P=$ Average population size of city in group of islands.

$J P P K=$ Smallest population size of city in group of islands

\section{C) Territorial borders}

a) Territorial borders between parent region and adjacent regions;

b) Territorial borders between proposed Preparation region and Parent region after deducting proposed Preparation region, shown by coordinates in basic map with scale 1:5000 and/or high resolution satellite image with spatial resolution of at least 4 (four) meters.

\section{D) Territorial coverage}

Territorial coverage of Preparation region includes:

a) At least 5 (five) districts for creation of regency; and

b) At least 4 (four) districts for creation of city.

Shown in:
a) Map of parent region's territorial
b) Map of Preparation region's territorial; and
c) Map of parent region's territorial after deducting with proposed Prepara- 
tion region's territorial.

E) Minimum age

Minimum ages of province, regency/city, and district, as mentioned in Article 6 clause (2) point e:

a) Minimum age of parent province is 10 (seven) years, from the date of creation;

b) Minimum age of parent regency/city is 7 (seven) years, from the date of creation;

c) Minimum age of regency/city under territorial coverage of Preparation region of province is 7 (seven) years, from the date of the creation;

d) Minimum age of district under territorial coverage of preparation regency/city is 5 (five) years, from the date of the creation

\section{2) Basic requirements of Regional capacity}

Evaluation of basic requirements of Regional capacity serves as basis for making decision on adequacy of a proposed Preparation region in terms of meeting the basic requirements of Regional capacity. Basic requirements of Regional capacity consists of several parameters, each parameter consists of 1 (one) or more indicator(s), and each indicator consists of 1 (one) or more sub-indicator(s). Parameter is main condition that serves as basis in evaluation of basic requirements of regional capacity. Parameter of basic requirements of regional capacity consists of:

1) Parameter of geography;

2) Parameter of demography;

3) Parameter of defense;

4) Parameter of social-politics, local custom, and traditions;

5) Parameter of economic potential;

6) Parameter of regional financial; and

7) Parameter of capability in governmental administration.

Each parameter consists of 1 (one) or more indicator(s). Indicator is a condition that is considered to be able to provide description on parameter more specifically. Each indicator is elaborated into sub-indicators. Sub-indicator is 1 (one) or more measurement(s) that is/are considered to be able to provide description more particularly on an indicator, either by data or fact from field. Sub-indicator should meet requirements as follows:

1) Data is available;

2) Calculable;

3) Relevant;

4) Measurable; and

5) Reliable.

Evaluation for requirement of regional capacity is conducted by calculating parameter, indicators, and sub-indicators to find score of sub-indicator, value of sub-indicator, total score, and criteria of adequacy. Each sub-indicator is scored. Application of scoring method to each sub-indicators is to: 
a) Maintain objectiveness;

b) Standardize way of evaluation; and

c) Facilitate calculation.

In scoring each sub-indicator, it should be preceded by defining range of score from 1 (one) to 5 (five), with 1 (one) as the lowest score and 5 (five) as the highest score. For most of sub-indicators, score 5 (five) indicates the maximum, best, or most expected condition, and score 1 (one) indicates the minimum, worst, or least expected condition. For sub-indicator of accessibility to basic service of education, health, and infrastructures, score 5 (five) indicates the minimum, worst or least expected condition. And score 1 (one 0 indicates an already maximum, best, or most expected condition. Score for each sub-indicator is shown as follows (Table 11).

Each sub-indicator has specific value. Value of each sub-indicator is distinctive according to its relative importance to indicator or parameter of basic requirements of Regional capacity. Sub-indicator that is considered to have relatively higher importance have greater value, and sub-indicator that is considered to have relatively lower importance have smaller value. Total score is accumulation of all Scores of Sub-indicators. To obtain total score, all Scores of Sub-indicators are accumulated. Criteria of adequacy to qualify basic requirements of Regional capacity is determined by categories as follows (Table 12).

Explanation:

A proposed Preparation region is declared adequate if having total score of 400 to 500 with category of capable. A proposed Preparation region is declared inadequate if having total score below 400 with category of incapable.

\section{Result}

Based on analysis of potential of districts in Natuna regency as elaborated in previous Chapter by 2 (two) analyses, i.e. According to GR No. 78 of 2007 with 11 (eleven) variables and GR No. 129 of 2000 with 19 (nineteen) variables and, it can be concluded that:

Result of Analysis of Potential of Natuna Regency according to GR No. 78 of 2007, there are 4 (four) alternatives for creation of new autonomous region in Natuna regency as shown in table below (Table 13).

Based on calculation above (Table 14), it can be explained that:

a) Of all proposed regencies, parent and formed, from alternative I to alternative IV, the ones to be recommended for formation are Alternative II (Parent with 5 districts and score of 352, New regency 1 with 5 districts and score of 353, New regency 1 with 5 districts and score of 340) and Alternative III (Parent with 5 districts and score of 363 , New regency 1 with 5 districts and score of 342, New regency 1 with 5 districts and score of 340), because based on result of analysis, all variables are included in category of Capable (340 419), thus recommended as new autonomous region. In addition, both alternatives (II and III) qualify in most of passing requirements as stated in GR No. 78 
Table 11. Calculation of regional capacity.

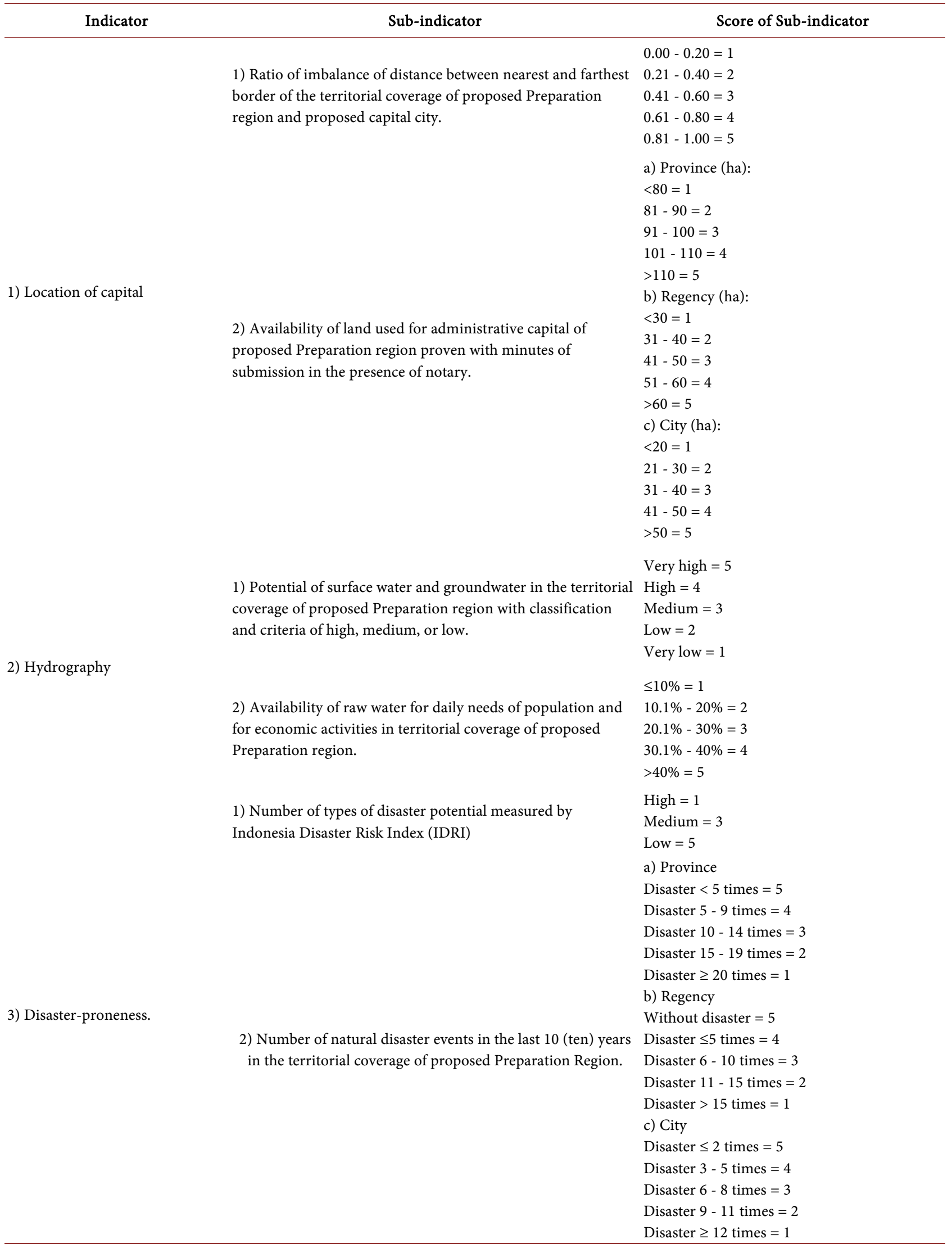




\section{Continued}

4) Quality of human resources

5) Distribution of population.

6) General criminal acts

7) Social conflicts.

8) Public participation in general election

9) Social cohesiveness
1) Ratio of schooling years rate in territorial coverage of $\geq 1.00=5$ proposed Preparation region to mean years of schooling based on grouping of lands or islands.

$0.90-0.99=4$

$0.70-0.79=2$

$<0.70=1$

$\geq 1.00=5$

2) Ratio of Gross Enrollment Rate (GER) for high school

$0.90-0.99=4$

$0.80-0.89=3$ education in territorial coverage of proposed Preparation

$0.70-0.79=2$

$<0.70=1$

$\geq 1.00=5$

3) Ratio of GER for elementary school education in territorial coverage of proposed Preparation Region to average GER

$0.90-0.99=4$

$0.80-0.89=3$

$0.70-0.79=2$

$<0.70=1$

$\geq 1.00=5$

Ratio of population density in territorial coverage of proposed $0.90-0.99=4$ Preparation Region to average population density based on $\quad 0.80-0.89=3$ grouping of lands or islands.

$0.70-0.79=2$

$<0.70=1$

Ratio of general crime rate per 10,000 population in territorial coverage of proposed Preparation region to average general crime rate per 10,000 population based on grouping of lands or islands.

$\geq 1.00=1$

$0.90-0.99=2$

$0.80-0.89=3$

$0.70-0.79=4$

$<0.70=5$

a) Province

Conflict $<5$ times $=5$

Conflict $5-9$ times $=4$

Conflict $10-14$ times $=3$

Conflict $15-19$ times $=2$

Conflict $\geq 20$ times $=1$

b) Regency

Without conflict $=5$

Number of social conflicts in territorial coverage of proposed Preparation region.

Conflict $\leq 5$ times $=4$

Conflict $6-10$ times $=3$

Conflict $11-15$ times $=2$

Conflict $>15$ times $=1$

c) City

Conflict $\leq 2$ times $=5$

Conflict $3-5$ times $=4$

Conflict $6-8$ times $=3$

Conflict $9-11$ times $=2$

Conflict $\geq 12$ times $=1$

$>70 \%=5$

Percentage of population participating in general election to $\quad 60 \%-70 \%=4$

population with voting right in territorial coverage of proposed $50 \%-59 \%=3$
Preparation region.
$40 \%-49 \%=2$

$<40 \%=1$

1 ethnics/sub-ethnics $=5$

2 - 3 ethnics/sub-ethnics $=4$

$4-5$ ethnics/sub-ethnics $=3$

$6-7$ ethnics/sub-ethnics $=2$

$>8$ ethnics/sub-ethnics $=1$ 


\section{Continued}

10) Social organization

11) Economic Growth

12) Regional core competence
Number of social organization registered according to laws in territorial coverage of proposed Preparation region.

1) Ratio of average economic growth for 5 (five) years in territorial coverage of proposed Preparation region to average economic growth based on grouping of lands or islands for 5 (five) years.

2) Ratio of population density in territorial coverage of proposed Preparation Region to average population density based on grouping of lands or islands.

3) Ratio of Human Development Index (HDI) in territorial coverage of proposed Preparation Region to HDI based on grouping of lands or islands.

4) Ratio of poverty rate in territorial coverage of proposed Preparation Region to poverty rate based on grouping of lands or islands.

1) Number of measured reserve of oil and gas in territorial coverage of proposed Preparation region.

2) Number of measured reserve of mineral and coal in territorial coverage of proposed Preparation region.

3) Number of measured reserve of geothermal in territorial coverage of proposed Preparation region.

4) Ratio of contribution of Gross Regional Domestic Product (GRDP) of agricultural sector per capita in parent region to contribution of Gross Domestic Product (GDP) of agricultural sector per national capita.
$>40$ Social organizations $=5$

$31-40$ Social organizations $=4$

$21-30$ Social organizations $=3$

$11-20$ Social organizations $=2$

$<10$ Social organizations $=1$

$\geq 1.00=5$

$0.90-0.99=4$

$0.80-0.89=3$

$0.70-0.79=2$

$<0.70=1$

$\geq 1.00=5$

$0.90-0.99=4$

$0.80-0.89=3$

$0.70-0.79=2$

$<0.70=1$

$\geq 1.00=5$

$0.90-0.99=4$

$0.80-0.89=3$

$0.70-0.79=2$

$<0.70=1$

$<0.70=5$

$0.70-0.79=4$

$0.80-0.89=3$

$0.90-0.99=2$

$\geq 1.00=1$

Available measured reserve is economically profitable and developed $=5$

Available measured reserve is economically profitable and undeveloped $=4$

Available measured reserve is economically unprofitable $=3$

Available reserve is not measured $=2$

No available reserve $=1$

Available measured reserve is economically profitable and developed $=5$

Available measured reserve is economically profitable and undeveloped $=4$

Available measured reserve is economically unprofitable $=3$

Available reserve is not measured $=2$

No available reserve $=1$

Available measured reserve is economically profitable and developed $=5$

Available measured reserve is economically profitable and undeveloped $=4$

Available measured reserve is economically unprofitable $=3$

Available reserve is not measured $=2$

No available reserve $=1$

$\geq 1.00=5$

$0.90-0.99=4$

$0.80-0.89=3$

$0.70-0.79=2$

$<0.70=1$ 
13) Capacity of parent region's local own source revenue

14) Potential of proposed preparation region's local own source revenue

15) Regional financial and asset management

16) Accessibility of basic service of education
5) Ratio of contribution of GRDP of industrial sector per capita in parent region to contribution of GDP of industrial sector per capita based on grouping of lands and islands.

$\geq 1.00=5$

$0.90-0.99=4$

$0.80-0.89=3$

$0.70-0.79=2$

$<0.70=1$

$\geq 1.00=5$

6) Ratio of contribution of GRDP of trade, hotel and restaurant $0.90-0.99=4$ sector per capita in parent region to contribution of GDP of $\quad 0.80-0.89=3$ trade, hotel and restaurant sector per national capita. $\quad 0.70-0.79=2$

$<0.70=1$

7) Ratio of contribution of GRDP of transportation and communication sector per capita in parent region to contribution of GDP of transportation and communication sector per capita based on grouping of lands and islands.

8) Ratio of contribution of GRDP of financial and rental sector per capita in parent region to contribution of GDP of financial and rental sector per capita based on grouping of lands and islands.

$\geq 1.00=5$

$0.90-0.99=4$

$0.80-0.89=3$

$0.70-0.79=2$

$<0.70=1$

$\geq 1.00=5$

$0.90-0.99=4$

$0.80-0.89=3$

$0.70-0.79=2$

$<0.70=1$

$\geq 1.00=5$

9) Ratio of contribution of GRDP of service sector per capita in $0.90-0.99=4$ parent region to contribution of GDP of service sector per $\quad 0.80-0.89=3$ capita based on grouping of lands and islands.

$0.70-0.79=2$

$<0.70=1$

$\geq 1.00=5$

Ratio of local own source revenue (OSR) of parent region to total revenue of parent region.

$0.90-0.99=4$

$0.80-0.89=3$

$0.70-0.79=2$

$<0.70=1$

$\geq 1.00=1$

Ratio of proposed preparation region's local own source revenue to OSR of parent region

$0.90-0.99=2$

$0.80-0.89=3$

$0.70-0.79=4$

$<0.70=5$

Unqualified Opinion 5 times in 5 years $=5$

Unqualified Opinion 4 times in 5 years $=4$

Opinion by Audit Board of Indonesia ( $B P K)$ on Local Government Financial Statement (LGFS) of parent region in the last 5 (five) years.

Unqualified Opinion 3 times in 5 years $=3$

Unqualified Opinion 3 times in 5 years $=2$

Unqualified Opinion 1 times in 5 years $=1$

$\leq 32=1$

1) Average number of elementary school $(S D)$ students in each $32-35=2$

classroom of $S D$ in territorial coverage of proposed $\quad 36-39=3$

Preparation region.

$40-42=4$

$\geq 43=5$

$\leq 32=1$

2) Average number of middle school ( $S M P)$ students in each classroom of $S M P$ in territorial coverage of proposed Preparation region.

$32-35=2$

$36-39=3$

$40-42=4$

$\geq 43=5$

$\leq 32=1$

$32-35=2$

$36-39=3$

$40-42=4$

$\geq 43=5$ 


\section{Continued}

17) Accessibility of basic service of health

18) Accessibility of basic service of infrastructures

19) Number of state civil apparatus in parent region

20) Draft spatial planning for proposed Preparation region
1) Ratio of number of doctor to population size in territorial coverage of proposed Preparation region.

$<2500=1$

$2500-2999=2$

$3000-3499=3$

$3500-3999=4$

$\geq 4000=5$

$\leq 1000=1$

2) Ratio of number of bed of hospital/community health center $1001-1500=2$ to population size in territorial coverage of proposed $\quad 1501-2000=3$ Preparation region.

$2001-2500=4$

$<2500=5$

$0.80-100=1$

1) Ratio of road length per area size in proposed Preparation $0.60-0.79=2$ region to average road length per average area size in group of $0.41-0.59=3$ lands and islands.

$0.21-0.40=4$

$<0.20=5$

$0.80-100=1$

2) Ratio of number of harbor connecting islands in territorial $0.60-0.79=2$ coverage of proposed Preparation region to average number of $0.41-0.59=3$ harbor in the group of lands and islands, for islands territory. $\quad 0.21-0.40=4$

$<0.20=5$

1) Ratio of number of state civil apparatus (SCA) per

$0.80-100=1$

$0.60-0.79=2$

$0.41-0.59=3$

$0.21-0.40=4$

$<0.20=5$

$0.80-100=1$

$0.60-0.79=2$

$0.41-0.59=3$

$0.21-0.40=4$

$<0.20=5$

Included in document of SP of parent region $=5$

Studied but not yet included in document of SP of parent region $=3$

Not studied yet $=1$

Table 12. Criteria of adequacy to qualify basic requirements of regional capacity.

\begin{tabular}{cccc}
\hline No. & Total Score & Category & Criteria of Adequacy \\
\hline 1. & $400-500$ & Capable & Adequate \\
2. & Below 400 & Incapable & Inadequate \\
\hline
\end{tabular}

of 2007, that for 4 (four) main factors should meet the standard, i.e. Demography (80 - 100), economic capability (60 - 75), regional potential (60 - 75), and financial capability $(60-75)$.

b) The main principle in formation of region is that it should not make proposed parent regency become weak or incapable to administer its autonomy, or capability between proposed formed regency and proposed parent regency after the formation should not have significant discrepancy.

Difference of score between proposed regencies can be calculated as follows (Table 15). 
Table 13. Alternatives of formed region.

\begin{tabular}{|c|c|c|c|}
\hline \multirow{2}{*}{ ALTERNATIVE } & \multicolumn{3}{|c|}{ NUMBER AND NAME OF DISTRICTS } \\
\hline & PROPOSED PARENT REGION & PROPOSED FORMED REGION I & PROPOSED FORMED REGION II \\
\hline 1 & 2 & 3 & 4 \\
\hline I & $\begin{array}{l}10 \text { districts: } \\
\text { Bunguran Selatan, Bunguran Tengah, } \\
\text { Bunguran TimurLaut, Bunguran Timur, } \\
\text { Bunguran Barat, Bunguran Batubi, } \\
\text { Bunguran Utara, Pulau Tiga Barat, } \\
\text { Pulau Tiga, and Pulau Laut }\end{array}$ & $\begin{array}{c}5 \text { districts: } \\
\text { Midai, Suak Midai, Serasan Timur, } \\
\text { Serasandan Subi }\end{array}$ & \\
\hline II & $\begin{array}{c}5 \text { districts: } \\
\text { Bunguran Selatan, Bunguran Tengah, } \\
\text { Bunguran Timur Laut, Bunguran Timur, } \\
\text { and Pulau Tiga }\end{array}$ & $\begin{array}{c}5 \text { districts: } \\
\text { Bunguran Barat, Bunguran Batubi, } \\
\text { Bunguran Utara, Pulau Tiga Barat } \\
\text { and Pulau Laut }\end{array}$ & $\begin{array}{c}5 \text { districts: } \\
\text { Midai, Suak Midai, Serasan Timur, } \\
\text { Serasandan Subi }\end{array}$ \\
\hline III & $\begin{array}{c}5 \text { districts: } \\
\text { Pulau Laut, Bunguran Utara, } \\
\text { Bunguran Selatan, Bunguran Tengah, } \\
\text { and Bunguran Timur Laut }\end{array}$ & $\begin{array}{c}5 \text { districts: } \\
\text { Bunguran Timur, Bunguran Barat, } \\
\text { Bunguran Batubi, Pulau Tiga and } \\
\text { Pulau Tiga Barat }\end{array}$ & $\begin{array}{c}5 \text { districts: } \\
\text { Midai, SuakMidai, Serasan Timur, } \\
\text { Serasandan Subi }\end{array}$ \\
\hline IV & $\begin{array}{c}4 \text { districts: } \\
\text { Bunguran Selatan, Bunguran Tengah, } \\
\text { Bunguran Timur Laut, and } \\
\text { Bunguran Timur }\end{array}$ & $\begin{array}{l}6 \text { districts: } \\
\text { Bunguran Barat, Bunguran Batubi, } \\
\text { Bunguran Utara, Pulau Tiga Barat, } \\
\text { PulauTiga, and Pulau Laut }\end{array}$ & $\begin{array}{c}5 \text { districts: } \\
\text { Midai, Suak Midai, Serasan Timur, } \\
\text { Serasan and Subi }\end{array}$ \\
\hline
\end{tabular}

Sources: Data process, 2017.

Table 14. Comparison of variables between natuna regency and proposed regency.

\begin{tabular}{|c|c|c|c|c|c|c|c|c|c|c|c|c|}
\hline \multirow{4}{*}{ No. } & \multirow{4}{*}{ VARIABLE } & \multicolumn{11}{|c|}{ SCORE $\times$ VALUE } \\
\hline & & \multirow{2}{*}{\multicolumn{4}{|c|}{$\begin{array}{c}\text { PROPOSED PARENT REGION } \\
\text { ALTERNATIVE }\end{array}$}} & \multicolumn{7}{|c|}{ PROPOSED FORMED REGION } \\
\hline & & & & & & \multicolumn{7}{|c|}{ ALTERNATIVE } \\
\hline & & I & II & III & IV & I & II.1 & II. 2 & III.1 & III. 2 & IV.1 & IV.2 \\
\hline 1. & Demography: & 100 & 100 & 100 & 100 & 100 & 100 & 100 & 100 & 100 & 100 & 100 \\
\hline 2. & Economic capability & 70 & 75 & 65 & 75 & 60 & 55 & 60 & 60 & 60 & 50 & 60 \\
\hline 3. & Regional Potential & 69 & 59 & 74 & 61 & 58 & 64 & 59 & 51 & 58 & 61 & 58 \\
\hline 4. & Financial Capability & 75 & 75 & 30 & 75 & 15 & 30 & 15 & 75 & 15 & 15 & 15 \\
\hline 5. & Socio-culture & 75 & 75 & 75 & 75 & 50 & 70 & 50 & 35 & 50 & 60 & 50 \\
\hline 6. & Socio-Politics & 25 & 25 & 25 & 25 & 20 & 21 & 20 & 16 & 20 & 21 & 20 \\
\hline 7. & Area Size & 25 & 25 & 19 & 25 & 11 & 22 & 11 & 25 & 11 & 19 & 11 \\
\hline 8. & Defense & 10 & 7 & 10 & 7 & 19 & 13 & 19 & 10 & 19 & 13 & 19 \\
\hline 9. & Security & 25 & 11 & 17 & 14 & 11 & 25 & 11 & 22 & 11 & 25 & 11 \\
\hline 10. & Social welfare rate & 25 & 25 & 25 & 25 & 20 & 20 & 20 & 20 & 20 & 20 & 20 \\
\hline \multirow[t]{2}{*}{11.} & Span of Control & 12 & 5 & 15 & 5 & 25 & 20 & 25 & 10 & 25 & 15 & 25 \\
\hline & Total & 511 & 482 & 455 & 487 & 389 & 440 & 390 & 424 & 389 & 399 & 389 \\
\hline
\end{tabular}

Sources: Data Process, 2017. 
Table 15. Difference of score between proposed regencies.

\begin{tabular}{|c|c|c|c|c|c|c|}
\hline \multirow{2}{*}{$\begin{array}{c}\text { No. } \\
1 .\end{array}$} & \multirow{2}{*}{$\begin{array}{c}\text { Alternatives of Formation } \\
\text { Alternative I }\end{array}$} & \multicolumn{5}{|c|}{ Difference between Proposed Regencies (Parent-Formed) } \\
\hline & & 511 & - & 389 & $=$ & $122(+)$ \\
\hline \multirow{2}{*}{2.} & \multirow{2}{*}{ Alternative II } & 482 & - & 440 & $=$ & $42(+)$ \\
\hline & & 482 & - & 390 & $=$ & $92(+)$ \\
\hline \multirow[b]{2}{*}{3.} & \multirow[b]{2}{*}{ Alternative III } & 455 & - & 424 & $=$ & $31(+)$ \\
\hline & & 455 & - & 389 & $=$ & $66(+)$ \\
\hline \multirow{2}{*}{4.} & \multirow{2}{*}{ Alternative IV } & 487 & - & 399 & $=$ & $88(+)$ \\
\hline & & 487 & - & 389 & $=$ & $98(+)$ \\
\hline
\end{tabular}

Sources: Data Process, 2017.

The positive sign (+) at the result of deduction above shows that potential of proposed parent regency is higher than of proposed formed regency. Table 15 shows that the minimum difference of score is in alternative II and III with difference of $42(+)$ and $92(+)$, and difference of $31(+)$ and $66(+)$. So, the priority of action taken for formation based on differences of total score that is recommended is only alternative II and alternative III, whereas alternative I and IV are not recommended because of failing to meet the standard for 4 variables. Departing from 2 alternatives above, it is recommended that:

1) First Recommendation: Alternative III is prioritized in the first place

Proposed Parent Regency: 5 districts, i.e. Pulau Laut, Bunguran Utara, Bunguran Selatan, Bunguran Tengah, and Bunguran Timur Laut.

$>$ Proposed Formed Region I: 5 districts, i.e. Bunguran Timur, Bunguran Barat, Bunguran Batubi, Pulau Tiga and Pulau Tiga Barat.

Proposed Formed Region II: 5 districts, i.e. Midai, Suak Midai, Serasan Timur, Serasan and Subi.

2) Second Recommendation: Alternative II is prioritized in the second place

> Proposed Parent Regency: 5 districts, i.e. Bunguran Selatan, Bunguran Tengah, Bunguran Timur Laut, Bunguran Timur, and Pulau Tiga.

$>$ Proposed Formed Region I: 5 districts, i.e. Bunguran Barat, Bunguran Batubi, Bunguran Utara, Pulau Tiga Barat and Pulau Laut.

Proposed Formed Region II: 5 districts, i.e. Midai, Suak Midai, Serasan Timur, Serasan and Subi.

3) Balance in real and potential capacity of regencies, either proposed formed regency and proposed parent regency, after the formation should be relatively maintained. Therefore, the choice of action is based on alternative with smallest difference of total score. Formation should also ensure the improvement of public services, democratization, and social welfare, of both proposed formed regency and proposed parent regency after the formation (Table 16).

From the result of calculation on capacity of proposed parent region with proposed formed region in relation with regencies/cities in Riau Islands Province, it 
Table 16. Potential of capability of regencies and cities in riau islands province.

\begin{tabular}{ccc}
\hline No. & REGENCY/CITY & TOTAL SCORE \\
\hline 1 & Karimun & 337 \\
2 & Bintan & 278 \\
3 & Natuna & 431 \\
4 & Lingga & 353 \\
5 & Anambas Islands & 343 \\
6 & Batam & 350 \\
7 & Tanjungpinang & 377 \\
\hline
\end{tabular}

Source: Data Processing, 2017.

is shown that alternative II and II have good score of capability, of which alternative II with proposed parent region I scored 482, proposed formed region I scored 440 and proposed formed region II scored 390, and of which alternative III with proposed parent region I scored 455, proposed formed region I scored 424 and proposed formed region II scored 389, which mean ABOVE AVERAGE of capability of regencies/cities in Riau Islands Province (Table 17).

Result of Analysis of Potential of Natuna Regency according to GR No. 129 of 2000 , regarding potential of districts of whether adequate, fairly adequate or inadequate for formation, is shown in Table 18.

Based on result of analysis above, of 15 districts in Natuna Regency, 9 districts have potential of adequate for formation, i.e. Bunguran Barat, Bunguran Batubi, Bunguran Utara, Pulau Tiga Barat, Bunguran Timur, Bunguran Timur Laut, Bunguran Tengah, Bunguran Selatan and Subi. And districts with potential of fairly adequate for formation are Midai, Suak Midai, Pulau Laut, Pulau Tiga, Serasan, and Serasan Timur. Mapping of districts in alternatives of formation of Natuna regency is as follows:

Mapping of districts in Natuna Regency in alternative 1 (Table 19) is parent regency with nominated districts of Bunguran Selatan, Bunguran Tengah, Bunguran Timur Laut, Bunguran Timur, Bunguran Barat, Bunguran Batubi, Bunguran Utara, Pulau Tiga Barat, Pulau Tiga, and Pulau Laut. And formed regency with nominated districts of Midai, Suak Midai, Serasan Timur, Serasan and Subi. For more detail, mapping of districts in alternative 1 of formation of Natuna regency is shown in map below (Figure 5).

Mapping of districts in Natuna Regency in alternative 2 (Table 20) is parent regency with nominated districts of Bunguran Selatan, Bunguran Tengah, Bunguran Timur Laut, Bunguran Timur, and Pulau Tiga. And formed regency I with nominated districts of Bunguran Barat, Bunguran Batubi, Bunguran Utara, Pulau Tiga Barat and Pulau Laut. And formed regency II with nominated districts of Midai, Suak Midai, Serasan Timur, Serasan and Subi. For more detail, mapping of districts in alternative 2 of formation of Natuna regency is shown in map below (Figure 6). 
Table 17. Comparison of score between proposed parent regency and proposed formed regency.

\begin{tabular}{ccc}
\hline No. & REGENCY/CITY & TOTAL SCORE \\
\hline 1 & PROPOSED PARENT REGION I & 511 \\
2 & PROPOSED PARENT REGION II & 482 \\
3 & PROPOSED PARENT REGION III & 455 \\
4 & PROPOSED PARENT REGION IV & 487 \\
5 & PROPOSED FORMED REGION I & 389 \\
6 & PROPOSED FORMED REGION II.1 & 440 \\
7 & PROPOSED FORMED REGION II.2 & 390 \\
8 & PROPOSED FORMED REGION III.1 & 424 \\
9 & PROPOSED FORMED REGION III.2 & 389 \\
10 & PROPOSED FORMED REGION III.1 & 399 \\
11 & PROPOSED FORMED REGION III.2 & 389 \\
\hline
\end{tabular}

Source: Data Processing, 2017.

Table 18. Potential of districts in whole natuna regency.

\begin{tabular}{|c|c|c|c|c|c|}
\hline No. & REGENCY & DISTRICT & $\begin{array}{l}\text { TOTAL } \\
\text { SCORE }\end{array}$ & $\begin{array}{c}\text { SCORE } \\
\text { INTERVAL }\end{array}$ & CATEGORY \\
\hline 1 & 2 & 3 & 4 & 5 & 6 \\
\hline 1 & & Midai & 911 & $644 \leq \mathrm{TS}<1008$ & Fairly Adequate \\
\hline 2 & & SuakMidai & 793 & $644 \leq \mathrm{TS}<1008$ & Fairly Adequate \\
\hline 3 & & Bunguran Barat & 1232 & $1008 \leq \mathrm{TS}<1,680$ & Adequate \\
\hline 4 & & BunguranBatubi & 1118 & $1008 \leq \mathrm{TS}<1680$ & Adequate \\
\hline 5 & & Bunguran Utara & 1124 & $1008 \leq \mathrm{TS}<1680$ & Adequate \\
\hline 6 & & PulauLaut & 913 & $644 \leq \mathrm{TS}<1008$ & Fairly Adequate \\
\hline 7 & & PulauTiga & 825 & $644 \leq \mathrm{TS}<1008$ & Fairly Adequate \\
\hline 8 & Natuna & PulauTiga Barat & 1070 & $1008 \leq \mathrm{TS}<1680$ & Adequate \\
\hline 9 & & BunguranTimur & 1093 & $1008 \leq \mathrm{TS}<1680$ & Adequate \\
\hline 10 & & BunguranTimur & 1147 & $1008 \leq \mathrm{TS}<1680$ & Adequate \\
\hline 11 & & Bunguran Tengah & 1148 & $1008 \leq \mathrm{TS}<1680$ & Adequate \\
\hline 12 & & Bunguran Selatan & 1141 & $1008 \leq \mathrm{TS}<1680$ & Adequate \\
\hline 13 & & Serasan & 936 & $644 \leq \mathrm{TS}<1008$ & Fairly Adequate \\
\hline 14 & & Subi & 1123 & $1008 \leq \mathrm{TS}<1680$ & Adequate \\
\hline \multirow[t]{3}{*}{15} & & SerasanTimur & 911 & $644 \leq \mathrm{TS}<1008$ & Fairly Adequate \\
\hline & TOTAL & & 15,528 & & \\
\hline & AVERAGE & & 1035 & & \\
\hline
\end{tabular}

Source: Data Processing, 2017. 
Table 19. Mapping of districts in natuna regency (Alternative 1).

\begin{tabular}{cccccc}
\hline & PROPOSED PARENT REGION & \multicolumn{5}{c}{ PROPOSED FORMED REGION } \\
\hline No. & DISTRICT & TOTAL & NO. & DISTRICT & TOTAL \\
\hline 1 & Bunguran Selatan & 1141 & 1 & Midai & 911 \\
2 & Bunguran Tengah & 1148 & 2 & Suak Midai & 793 \\
3 & BunguranTimur & 1147 & 3 & Serasan Timur & 911 \\
4 & Bunguran Timur & 1093 & 4 & Serasan & 936 \\
5 & Bunguran Barat & 1232 & 5 & Subi & 1123 \\
6 & Bunguran Batubi & 1118 & & & \\
7 & Bunguran Utara & 1124 & & & \\
8 & Pulau Tiga Barat & 1070 & & & \\
9 & PulauTiga & 825 & & & \\
10 & PulauLaut & 913 & & \\
& AVERAGE SCORE & 1081 & AVERAGE SCORE & \\
& DIFFERENCE OF SCORE & & & \\
\end{tabular}

Sources: Data Processing, 2017.

Table 20. Mapping of districts in natuna regency (Alternative 2).

\begin{tabular}{|c|c|c|c|c|c|c|c|c|}
\hline \multicolumn{3}{|c|}{ PROPOSED PARENT REGION } & \multicolumn{3}{|c|}{$\begin{array}{l}\text { PROPOSED FORMED } \\
\text { REGION I }\end{array}$} & \multicolumn{3}{|c|}{$\begin{array}{l}\text { PROPOSED FORMED } \\
\text { REGION II }\end{array}$} \\
\hline No. & DISTRICT & TOTAL & NO & DISTRICT & TOTAL & No. & DISTRICT & TOTAL \\
\hline 1 & Bunguran Selatan & 1141 & 1 & Bunguran Barat & 1232 & 1 & Midai & 911 \\
\hline 2 & Bunguran Tengah & 1148 & 2 & Bunguran Batubi & 1118 & 2 & Suak Midai & 793 \\
\hline 3 & Bunguran Timur & 1147 & 3 & Bunguran Utara & 1124 & 3 & $\begin{array}{c}\text { Serasan } \\
\text { Timur }\end{array}$ & 911 \\
\hline 4 & Bunguran Timur & 1093 & 4 & Pulau Tiga Barat & 1070 & 4 & Serasan & 936 \\
\hline 5 & Pulau Tiga & 825 & 5 & PulauLaut & 913 & 5 & Subi & 1123 \\
\hline \multicolumn{2}{|c|}{ AVERAGE SCORE } & 1071 & & ERAGE SCORE & 1091 & \multicolumn{2}{|c|}{$\begin{array}{l}\text { AVERAGE } \\
\text { SCORE }\end{array}$} & 935 \\
\hline \multicolumn{2}{|c|}{$\begin{array}{l}\text { DIFFERENCE OF } \\
\text { SCORE }\end{array}$} & \multicolumn{4}{|c|}{ (21) } & \multicolumn{2}{|r|}{136} & \\
\hline
\end{tabular}

Sources: Data Process, 2017.

Mapping of districts in Natuna Regency in alternative 3 (Table 21) is parent regency with nominated districts of Pulau Laut, Bunguran Utara, Bunguran Selatan, Bunguran Tengah, and Bunguran Timur Laut. And formed regency I with nominated districts of Bunguran Timur, Bunguran Barat, Bunguran Batubi, Pulau Tiga and Pulau Tiga Barat. And formed regency II with nominated districts of Midai, Suak Midai, Serasan Timur, Serasan and Subi. For more detail, mapping of districts in alternative 3 of formation of Natuna regency is shown in map below (Figure 7).

Mapping of districts in Natuna Regency in alternative 4 (Table 22) is parent regency with nominated districts of buNGUran Selatan, Bunguran Tengah, 


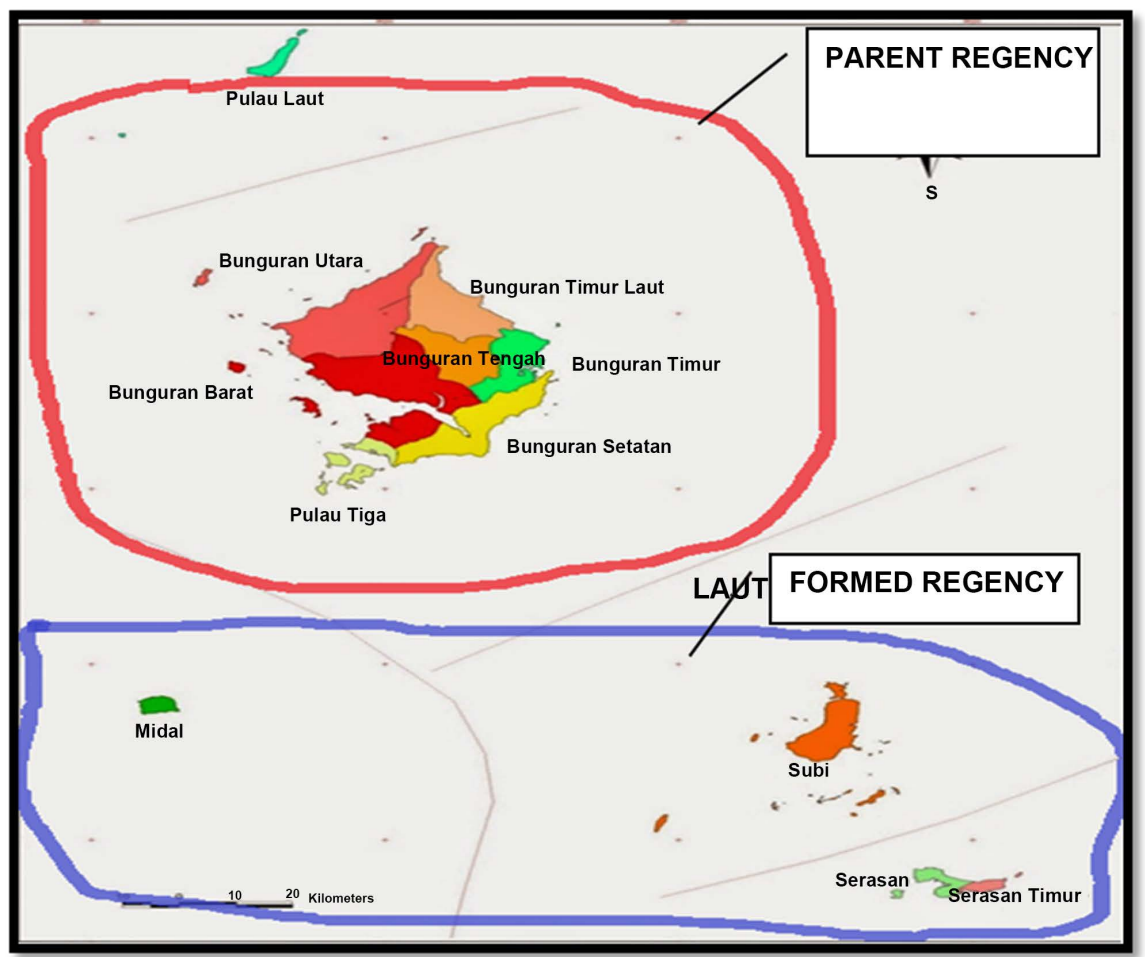

Figure 5. Map for mapping of districts in natuna regency (Alternative 1). Sources: Data Process, 2017.

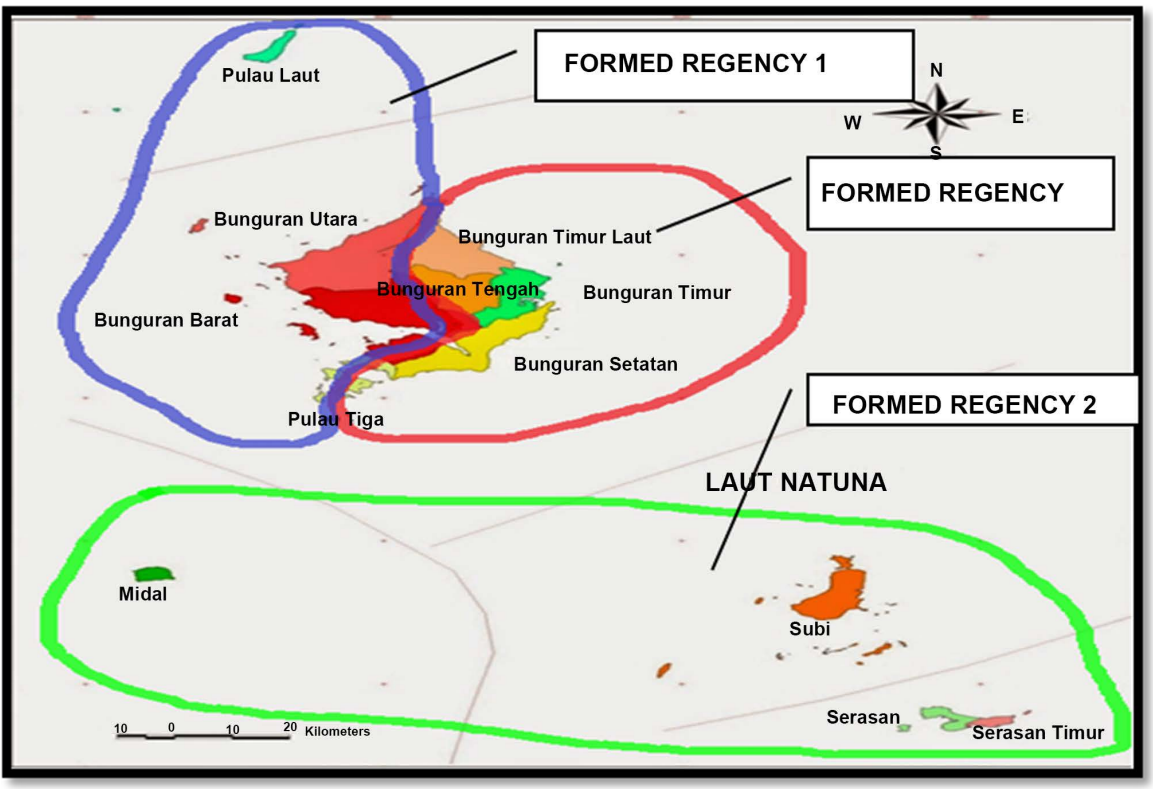

Figure 6. Map for mapping of districts in natuna regency (Alternative 2). Sources: Data Process, 2017.

Bunguran Timur Laut, and Bunguran Timur.. And formed regency I with nominated districts of Bunguran Barat, Bunguran Batubi, Bunguran Utara, Pulau Tiga Barat, Pulau Tiga and Pulau Laut. And formed regency II with nominated districts of Midai, Suak Midai, Serasan Timur, Serasan and Subi. For more detail, 
Table 21. Mapping of districts in natuna regency (Alternative 3).

\begin{tabular}{|c|c|c|c|c|c|c|c|c|}
\hline \multicolumn{3}{|c|}{$\begin{array}{c}\text { PROPOSED PARENT } \\
\text { REGION }\end{array}$} & \multicolumn{3}{|c|}{$\begin{array}{c}\text { PROPOSED FORMED } \\
\text { REGION I }\end{array}$} & \multicolumn{3}{|c|}{$\begin{array}{c}\text { PROPOSED FORMED } \\
\text { REGION II }\end{array}$} \\
\hline No. & DISTRICT & TOTAL & NO & DISTRICT & TOTAL & NO & DISTRICT & TOTAL \\
\hline 1 & Pulau Laut & 913 & 1 & $\begin{array}{c}\text { Bunguran } \\
\text { Timur }\end{array}$ & 1093 & 1 & Midai & 911 \\
\hline 2 & Bunguran Utara & 1124 & 2 & Bunguran Barat & 1232 & 2 & Suak Midai & 793 \\
\hline 3 & $\begin{array}{c}\text { Bunguran } \\
\text { Selatan }\end{array}$ & 1141 & 3 & $\begin{array}{c}\text { Bunguran } \\
\text { Batubi }\end{array}$ & 1118 & 3 & Serasan Timur & 911 \\
\hline 4 & $\begin{array}{l}\text { Bunguran } \\
\text { Tengah }\end{array}$ & 1148 & 4 & Pulau Tiga & 825 & 4 & Serasan & 936 \\
\hline 5 & $\begin{array}{l}\text { Bunguran } \\
\text { Timur }\end{array}$ & 1147 & 5 & $\begin{array}{l}\text { Pulau Tiga } \\
\text { Barat }\end{array}$ & 1070 & 5 & Subi & 1123 \\
\hline \multicolumn{2}{|c|}{ AVERAGE SCORE } & 1095 & AVH & RAGE SCORE & 1068 & \multicolumn{2}{|c|}{ AVERAGE SCORE } & 935 \\
\hline \multicolumn{2}{|c|}{$\begin{array}{l}\text { DIFFERENCE OF } \\
\text { SCORE }\end{array}$} & \multicolumn{4}{|c|}{27} & \multicolumn{2}{|r|}{160} & \\
\hline
\end{tabular}

Sources: Data Process, 2017.

Table 22. Mapping of districts in natuna regency (Alternative 4).

\begin{tabular}{|c|c|c|c|c|c|c|c|c|}
\hline \multicolumn{3}{|c|}{$\begin{array}{c}\text { PROPOSED PARENT } \\
\text { REGION }\end{array}$} & \multicolumn{3}{|c|}{$\begin{array}{l}\text { PROPOSED FORMED } \\
\text { REGION I }\end{array}$} & \multicolumn{3}{|c|}{$\begin{array}{l}\text { PROPOSED FORMED } \\
\text { REGION II }\end{array}$} \\
\hline No. & DISTRICT & TOTAL & No. & DISTRICT & TOTAL & No. & DISTRICT & TOTAL \\
\hline 1 & $\begin{array}{l}\text { Bunguran } \\
\text { Selatan }\end{array}$ & 1141 & 1 & Bunguran Barat & 1232 & 1 & Midai & 911 \\
\hline 2 & $\begin{array}{l}\text { Bunguran } \\
\text { Tengah }\end{array}$ & 1148 & 2 & $\begin{array}{l}\text { Bunguran } \\
\text { Batubi }\end{array}$ & 1118 & 2 & Suak Midai & 793 \\
\hline 3 & $\begin{array}{l}\text { Bunguran } \\
\text { Timur }\end{array}$ & 1147 & 3 & Bunguran Utara & 1124 & 3 & $\begin{array}{c}\text { Serasan } \\
\text { Timur }\end{array}$ & 911 \\
\hline \multirow[t]{3}{*}{4} & $\begin{array}{l}\text { Bunguran } \\
\text { Timur }\end{array}$ & 1093 & 4 & $\begin{array}{l}\text { Pulau Tiga } \\
\text { Barat }\end{array}$ & 1070 & 4 & Serasan & 936 \\
\hline & & & 5 & Pulau Tiga & 825 & 5 & Subi & 1123 \\
\hline & & & 6 & Pulau Laut & 913 & \multirow{2}{*}{\multicolumn{2}{|c|}{$\begin{array}{c}\text { AVERAGE } \\
\text { SCORE }\end{array}$}} & \\
\hline \multicolumn{2}{|c|}{ AVERAGE SCORE } & 1132 & \multicolumn{2}{|c|}{ AVERAGE SCORE } & 1047 & & & 935 \\
\hline \multicolumn{2}{|c|}{$\begin{array}{l}\text { DIFFERENCE OF } \\
\text { SCORE }\end{array}$} & & \multicolumn{2}{|r|}{85} & & \multicolumn{2}{|r|}{197} & \\
\hline
\end{tabular}

Sources: Data Process, 2017.

mapping of districts in alternative 4 of formation of Natuna regency is shown in map below (Figure 8, Table 23).

District with minimum score is Suak Midai by 793. District with maximum score is Bunguran Barat by 1,232. Difference of regional potential of villages in Natuna Regency between the highest and the lowest score is 439 or $55.4 \%$ of the lowest regional potential of district. For more complete comparison of potential per district in Natuna Regency between the highest and the lowest potential, the result can be shown as follows (Table 24).

Villages in Natuna Regency with potential of equal to or greater than the lowest regional potential of district by $30 \%$ can be said as having great potential for 


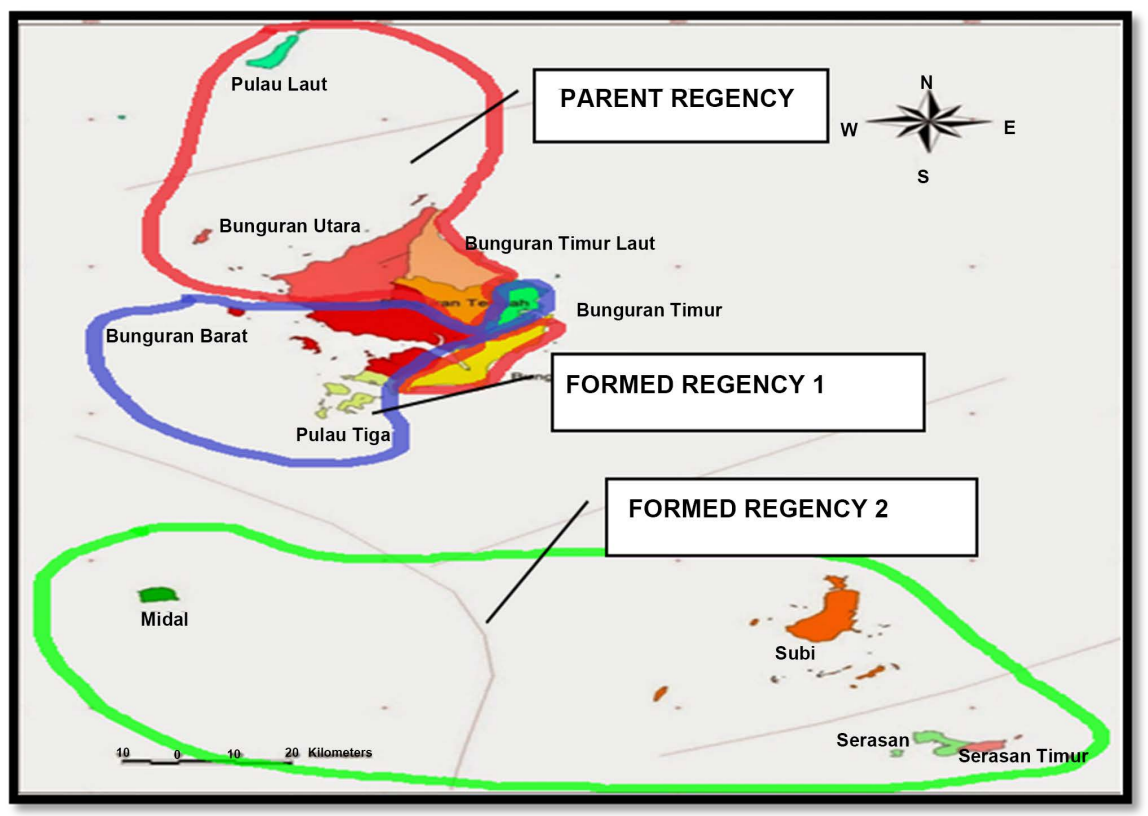

Figure 7. Map for mapping of districts in natuna regency (Alternative 3). Sources: Data Process, 2017.

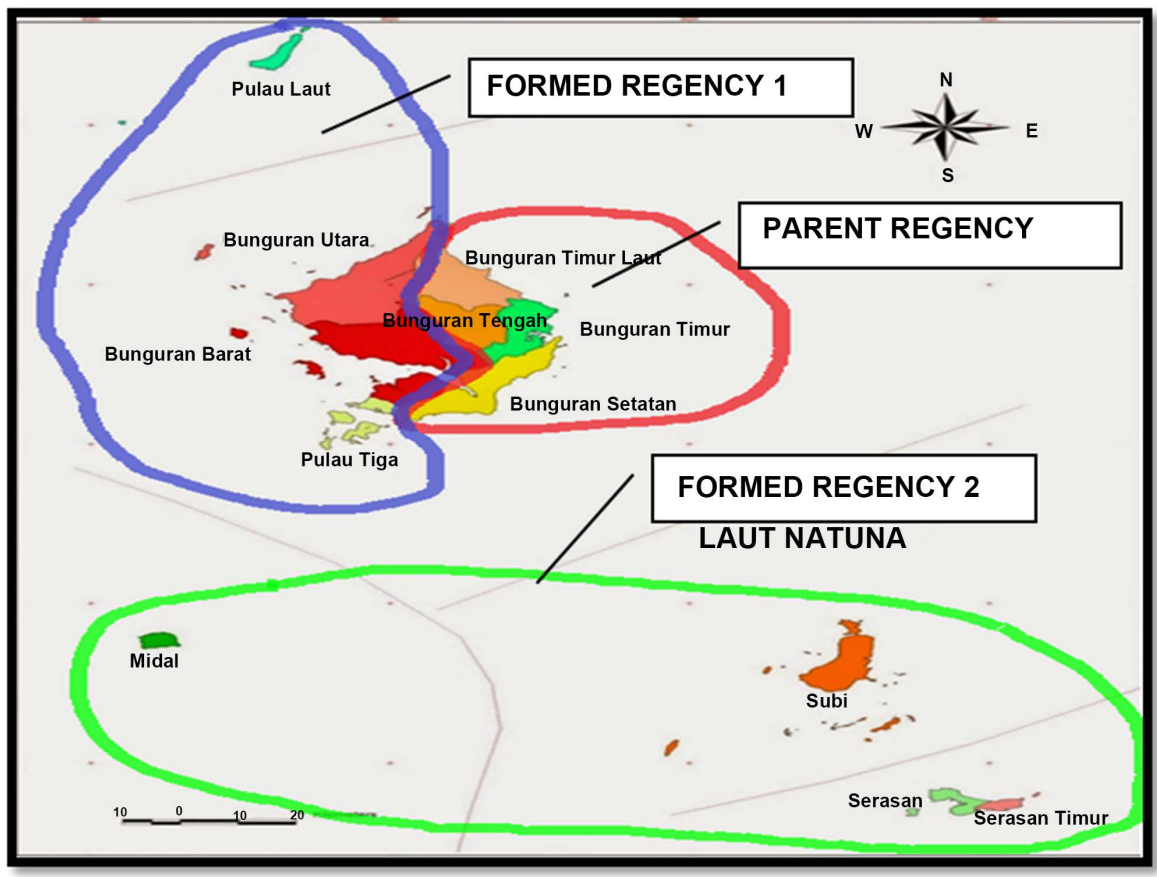

Figure 8. Map for mapping of districts in natuna regency (Alternative 4) Sources: Data Process, 2017.

formation. Based on Table 24, the result shows that from 15 (fifteen) districts in Natuna Regency, there are 24 (twenty-four) nominated districts can be formed if formation to be implemented. Districts that are adequate and have better potential for formation are Bunguran Barat, Bunguran Batubi, Bunguran Utara, Pulau Tiga Barat, Bunguran Timur, Bunguran Timur Laut, Bunguran Tengah, Bunguran 
Table 23. Mapping of districts in natuna regency.

\begin{tabular}{cccccc}
\hline \multirow{2}{*}{ Mapping } & \multicolumn{3}{c}{ Score Average } & Dafference 1 & Difference 2 \\
\cline { 2 - 4 } & $\begin{array}{c}\text { Parent } \\
\text { Regency }\end{array}$ & $\begin{array}{c}\text { Formed } \\
\text { District 1 }\end{array}$ & $\begin{array}{c}\text { Formed } \\
\text { District 2 }\end{array}$ & & \\
\hline Alternative 1 & 1081 & 935 & & 146 & 136 \\
Alternative 2 & 1071 & 1091 & 935 & -21 & 162 \\
Alternative 3 & 1095 & 1068 & 935 & 27 & 197 \\
Alternative 4 & 1132 & 1047 & 935 & 85 & \\
\hline
\end{tabular}

Sources: Data Process, 2017.

Table 24. Comparison of potential of districts in natuna regency.

\begin{tabular}{|c|c|c|c|c|c|c|}
\hline No. & REGENCY & DISTRICT & $\begin{array}{l}\text { TOTAL } \\
\text { SCORE }\end{array}$ & DIFFERENCE & $\%$ & $\begin{array}{c}\text { Nominated } \\
\text { District }\end{array}$ \\
\hline 1 & 2 & 3 & 4 & 5 & 6 & 7 \\
\hline 1 & & Midai & 911 & 118 & 15 & 1 \\
\hline 2 & & SuakMidai & 793 & 0 & 0 & 1 \\
\hline 3 & & Bunguran Barat & 1232 & 439 & 55 & 2 \\
\hline 4 & & BunguranBatubi & 1118 & 325 & 41 & 2 \\
\hline 5 & & Bunguran Utara & 1124 & 331 & 42 & 2 \\
\hline 6 & & PulauLaut & 913 & 120 & 15 & 1 \\
\hline 7 & & PulauTiga & 825 & 32 & 4 & 1 \\
\hline 8 & Natuna & PulauTiga Barat & 1070 & 277 & 35 & 2 \\
\hline 9 & & BunguranTimur & 1093 & 300 & 38 & 2 \\
\hline 10 & & BunguranTimur & 1147 & 354 & 45 & 2 \\
\hline 11 & & Bunguran Tengah & 1148 & 355 & 45 & 2 \\
\hline 12 & & Bunguran Selatan & 1141 & 348 & 44 & 2 \\
\hline 13 & & Serasan & 936 & 143 & 18 & 1 \\
\hline 14 & & Subi & 1,123 & 330 & 42 & 2 \\
\hline 15 & & SerasanTimur & 911 & 118 & 15 & 1 \\
\hline \multicolumn{6}{|c|}{ TOTAL } & 24 \\
\hline
\end{tabular}

Sources: Data Process, 2017.

Selatan and Subi. Therefore, formation of district has contribution to formation of Natuna regency.

\section{a) Alternative 1 (score difference by 146)}

* Proposed parent regency with score of 1081 consists of 10 districts, i.e. Bunguran Selatan, Bunguran Tengah, Bunguran Timur Laut, Bunguran Timur, Bunguran Barat, Bunguran Batubi, Bunguran Utara, Pulau Tiga Barat, Pulau Tiga, and Pulau Laut.

* Proposed formed regency with score of 935 consists of 5 districts, i.e. Midai, Suak Midai, Serasan Timur, Serasan and Subi. 
b) Alternative 2 (score differences-21 and 136)

* Proposed Parent Regency: with score of 1071 consists of 5 districts, i.e. Bunguran Selatan, Bunguran Tengah, Bunguran Timur Laut, Bunguran Timur, and Pulau Tiga.

* Proposed formed regency I with score of 1091 consists of 5 districts, i.e. Bunguran Barat, Bunguran Batubi, Bunguran Utara, Pulau Tiga Barat and Pulau Laut.

* Proposed formed regency II with score of 935 consists of 5 districts, i.e. Midai, Suak Midai, Serasan Timur, Serasan and Subi.

c) Alternative 3 (score differences 27 and 160)

- Proposed Parent Regency: with score of 1095 consists of 5 districts, i.e. Pulau Laut, Bunguran Utara, Bunguran Selatan, Bunguran Tengah, and Bunguran Timur Laut.

* Proposed formed regency I with score of 1068 consists of 5 districts, i.e. Bunguran Timur, Bunguran Barat, Bunguran Batubi, Pulau Tiga and Pulau Tiga Barat.

* Proposed formed regency II with score of 935 consists of 5 districts, i.e. Midai, Suak Midai, Serasan Timur, Serasan and Subi.

d) Alternative 4 (score differences 85 and 197)

* Proposed Parent Regency with score of 1132 consists of 4 districts, i.e. Bunguran Selatan, Bunguran Tengah, Bunguran Timur Laut, Bunguran Timur, and Bunguran Timur.

* Proposed formed regency I with score of 1047 consists of 6 districts, i.e. Bunguran Barat, Bunguran Batubi, Bunguran Utara, Pulau Tiga Barat, Pulau Tiga and Pulau Laut.

* Proposed formed regency II with score of 935 consists of 5 districts, i.e. Midai, Suak Midai, Serasan Timur, Serasan and Subi.

Based on the criteria, priority for formation can be seen in Table 25 .

Based on Table 25, it shows that alternative 2 that consists of Proposed Parent Regency (Bunguran Selatan, Bunguran Tengah, Bunguran Timur Laut, Bunguran Timur, and Pulau Tiga), Proposed Formed Regency I (Bunguran Barat, Bunguran Batubi, Bunguran Utara, Pulau Tiga Barat and Pulau Laut), Proposed Formed Regency II (Midai, Suak Midai, Serasan Timur, Serasan and Subi) is defined as choice 1 . This is based on consideration that formation according to division of governmental working area is relatively more balanced in terms of potential than formation by alternative 1, 3 and 4 regarding the 19 variables. Differences between proposed parent regency and proposed formed regency 1 and 2 in alternative 2 are -21 and 136, while average difference in alternative 1 is 146, in alternative 3 are 27 and 160, and in alternative 4 are 85 and 197.

\section{Conclusions}

Balance in real and potential capacity of regencies, either proposed formed regency or proposed parent regency, after the formation should be relatively 
Table 25. Choice of priority for alternatives of formation of regency in natuna regency.

\begin{tabular}{|c|c|c|c|c|}
\hline No. & ALTERNATIVE & CALCULATION & DIFFERENCE & PRIORITY \\
\hline 1. & $\begin{array}{c}\text { Alternative } 1 \\
\text { Proposed Parent Regency and } \\
\text { Proposed Formed Regency }\end{array}$ & $1081-935$ & 146 & III \\
\hline 2. & $\begin{array}{l}\text { Alternative } 2 \\
\text { Proposed Parent Regency and } \\
\text { Proposed Formed Regency I, } \\
\text { Proposed Formed Regency II }\end{array}$ & $\begin{array}{c}1071-1091 \\
1071-935\end{array}$ & $\begin{array}{l}(21) \\
136\end{array}$ & I \\
\hline 3. & $\begin{array}{l}\text { Alternative } 3 \\
\text { Proposed Parent Regency and } \\
\text { Proposed Formed Regency I, } \\
\text { Proposed Formed Regency II }\end{array}$ & $\begin{array}{c}1095-1068 \\
1095-935\end{array}$ & $\begin{array}{c}27 \\
160\end{array}$ & II \\
\hline 4. & $\begin{array}{l}\text { Alternative } 4 \\
\text { Proposed Parent Regency and } \\
\text { Proposed Formed Regency I, } \\
\text { Proposed Formed Regency II }\end{array}$ & $\begin{array}{c}1132-1047 \\
1132-935\end{array}$ & $\begin{array}{c}85 \\
197\end{array}$ & IV \\
\hline
\end{tabular}

Sources: Data Process, 2017.

maintained. Therefore, the choice of action is based on alternative with smallest difference of total score. Formation should also ensure the improvement of public services, democratization, and social welfare, of both proposed formed regency and proposed parent regency after the formation.

Priority choice for formation of Natuna Regency should be determined according to criteria on the lowest difference between results of proposed formed regencies, of both proposed created regency and proposed formed regency/proposed parent regency after formation, by considering public aspiration. This criterion is chosen with consideration:

1) Formation of regency should not make proposed parent regency become weak or incapable to administer its autonomy;

2) Difference of capability between proposed formed regency and proposed parent regency after the formation should not have significant discrepancy;

3) Balance in real and potential capacity of regencies, either proposed formed regency and proposed parent regency, after the formation should be relatively maintained;

4) Formation should ensure the improvement of public services, democratization, and social welfare, of both proposed formed regency and proposed parent regency after the formation.

Based on result of analysis, there are several factors need to be considered in improving regional capability to ensure the successful implementation of regional autonomy policy. The policy to be made for proposed formed regency and proposed parent regency includes:

1) Improvement of economic capability through:

Creating investment opportunity by considering the most flexible sub-sector of GRDP in improving the productiveness and employment rate.

2) Development of Regional Potential 
Table 26. Checklist for requirements of creation of natuna regency.

\begin{tabular}{|c|c|c|}
\hline Requirement & Qualified & Unqualified \\
\hline \multicolumn{3}{|l|}{ a) Administrative } \\
\hline - Approval by Regent & & $\sqrt{ }$ \\
\hline - Approval by Regional House of Representative of Regency & & $\sqrt{ }$ \\
\hline - Approval by Governor & & $\sqrt{ }$ \\
\hline - Approval by Regional House of Representative of Province & & $\sqrt{ }$ \\
\hline - $\quad$ Recommendation by Ministry of Home Affairs & & $\sqrt{ }$ \\
\hline \multicolumn{3}{|l|}{ b) Technical } \\
\hline - $\quad$ Total Score $>340$ & $\sqrt{ }$ & \\
\hline - $\quad$ Score for demography $>80$ & $\sqrt{ }$ & \\
\hline - Score for Economic capability $>60$ & $\sqrt{ }$ & \\
\hline - Score for Regional Potential $>60$ & $\sqrt{ }$ & \\
\hline - $\quad$ Score for Financial Capability $>60$ & $\sqrt{ }$ & \\
\hline \multicolumn{3}{|l|}{ c) Territorial Physical } \\
\hline - Number of district is at least 5 districts & $\sqrt{ }$ & \\
\hline \multicolumn{3}{|l|}{ d) Min. Age of Governmental Administration } \\
\hline - $\quad$ Parent Regency $>7$ years & $\sqrt{ }$ & \\
\hline - $\quad$ All districts in Proposed Formed Regency $>5$ years & $\sqrt{ }$ & \\
\hline \multicolumn{3}{|l|}{ e) Age of Preparation Region } \\
\hline - $\quad$ Stewardship in 3 years & & $\sqrt{ }$ \\
\hline - Evaluation post Preparation Region & & $\sqrt{ }$ \\
\hline - Categorized as ADEQUATE after evaluation & & $\sqrt{ }$ \\
\hline
\end{tabular}

Sources: Data Process, 2017.

Increasing quantity of Banking and non-Bank Financial Institution, such as cooperative, pawnshop and insurance, especially at the central of economic growth.

Increasing the quantity and quality of distribution of economic center, especially shopping center.

Improving the quantity and quality of educational facilities, especially high school level, according to needs of the region.

Improving the quantity and quality of health facilities for community in form of hospital, community health center and polyclinic.

Providing public services that are accessible by community, especially public transportation, facilitation for 2-wheel motor vehicle ownership, communication facilities such as land line, electricity, and post office and other services.

Providing tourism/recreation facilities and accommodation facilities such as restaurant. 
Providing labor intensive employment.

3) Improvement of financial capability

Exploring the potential for Local OSR.

Efficiency in routine expenses by Standard of Cost Analysis and Standard of Minimum Service.

4) Development of Socio-cultural Capacity

Developing social facilities and infrastructures for community, such as art performance place and orphanage.

5) Development of Socio-political Capacity

> Facilitating the establishment and empowerment of social organization and building the political awareness of the community.

6) Exploitation of Area Size

$>$ Efficiency and optimization of land for industry and commercial sectors, and for residential area.

7) Security and Defense

Improving the capacity of civilian defense, social security and order by involving public participation.

In addition to technical, administrative, and territorial physical requirements, creation of new autonomous region requires special attention so that it will runs according to things mentioned (Table 26).

\section{References}

[1] Nasution, A.B. (2000) Federalism for Indonesia. PT. Kompas Media Nusantara, Jakarta.

[2] Indonesia, Ministry of Home Affairs (2007) Government Regulation No. 78 of 2007 on Procedures on Creasion, Elimination and Merging of Regions. Regulation.

[3] BAPPENAS and UNDP (2008) Study of Evaluation of the Impact of Regional Division 2001-2007. The National Development Planning Agency of the Republic of Indonesia, Jakarta.

[4] (2016) Study of Evaluation of the Impact of Regional Division 2009-2015. The Nasional Develoment Planning Agency of Republic of Indonesia, Jakarta.

[5] Natuna, Biro Pusat Statistik (The Statistics Center) (2015) Natuna Regency in Number 2015. Regency of Natuna, Natuna.

[6] Province, Biro Pusat Statistiik (The Statistics Centre) Riau Islands (2015) Riau Islands Province in Number 2015. Province of Riau Islands, Riau Islands.

[7] Wasistiono, S., et al. (2002) Reorganized District Government Institutions. Government Study Centre STPDN-PT, Bandung. Citra Pindo.

[8] Wasistiono, S., et al. (2009) Development of District Organization from Time to Time. Institute of Local Government Management Studies-PT, Bandung. Fokusmedia.

[9] Nari, M. (2010) Social Dynamics and Regional Division. PT, Yogyakarta. Ombak.

[10] Simangunsong, F. (2014) Divison Regional Post-Birth of Law Number 23 Year 2014 about Local Government. Lecture Papers for Graduate School (Masters and Doctorate) at the Institute of Domestic Government, Bandung. (No Published)

[11] Indonesia, Manistry of Home Affairs (2000) Government Regulation (GR) No. 129 
of 2000 on Procedures on Creation, Elimination and Marging of Regions. Indonesia. Regulation.

[12] Indonesia, Minsitry of Home Affairs (1999) Law No. 22 of 1999 on Local Government. Indonesia. Regulation.

[13] Indonesia, Ministry of Home Affairs (2004) Law No. 32 of 2004 on Local Government, Indonesia. Regulation.

[14] Government Regulation (GR) (2007) No. 78 of 2007 on Procedures on Creation, Elimination, and Marging of Regions, Indonesia. Regulation.

[15] Indonesia, Minsitry of Home Affairs (2014) Law No. 23 of 2014 on Local Government, Indonesia. Regulation.

[16] Indonesia, Ministry of Home Affairs (2017) Draft Government Regulation (GR) of 2017 on Regional Reorganization, Indonesia. Regulation.

[17] Wignosubroto, S., et al. (2005) Tidal Autonomous Region-Sketches 100-Year Journey. Institute for Local Development-TIFA Foundation, Jakarta.

[18] Ratnawati, T. (2009) Regional Division-Politics and Some Selected Issues. PT. Pustaka Pelajar, Yogyakarta. 